\title{
Tectonic inheritance and Pliocene-Pleistocene inversion of the Algerian margin around Algiers: Insights from multibeam and seismic reflection data
}

\author{
Pierre Strzerzynski, ${ }^{1,2,3}$ Jacques Déverchère, ${ }^{1,2}$ Antonio Cattaneo, ${ }^{4}$ Anne Domzig, ${ }^{5}$ \\ Karim Yelles, ${ }^{6}$ Bernard Mercier de Lépinay, ${ }^{7}$ Nathalie Babonneau, ${ }^{1,2}$ \\ and Azzedine Boudiaf ${ }^{6}$
}

Received 2 June 2009; revised 8 September 2009; accepted 25 September 2009; published 30 March 2010.

[1] The Algerian margin has originated from the opening of the Algerian basin about 25-30 Ma ago. The central margin provides evidence for large-scale normal faults of Oligo-Miocene age, whereas transcurrent tectonics characterizes the western margin. A set of NW-SE oriented dextral transform faults was active during basin opening and divided the $600 \mathrm{~km}$ long central margin into segments of $\sim 120-150 \mathrm{~km}$. The upper Miocene, Plio-Quaternary, and present-day tectonic setting is, however, compressional and supports the occurrence of a margin inversion, a process still poorly documented worldwide. We show that the central Algerian margin represents a rare example of inverted margin, where the process of subduction inception is particularly well expressed and helps understand how extensional and transtensive structures are involved in margin shortening. Using multibeam bathymetry and multichannel seismic reflection sections from the MARADJA 2003 and 2005 cruises, we evidence PliocenePleistocene shortening with contrasting styles along the margin between west (Khayr Al Din bank) and east (Boumerdès-Dellys margin) of Algiers. Pre-Miocene structures such as basement highs and transform faults appear to control changes of the deformation pattern along this part of the margin, resulting in different widths, geometries, and relative positions of folds and faults. Plio-Quaternary and active blind thrust faults do not reuse Oligo-Miocene normal and transform faults during inversion, but instead grow within the continental margin (as testified for instance by the 21 May

\footnotetext{
${ }^{1}$ Domaines Océaniques, Université Européenne de Bretagne, Brest, France.

${ }^{2}$ Domaines Océaniques, UMR 6538, Université de Brest Occidentale, IUEM, CNRS, Plouzané, France.

${ }^{3}$ Now at Laboratoire de Planétologie et Géodynamique, UMR 6112, Université du Maine, CNRS, Le Mans, France.

${ }^{4}$ Laboratoire Environnements Sédimentaires, Département Géosciences Marines, IFREMER, Plouzané, France.

${ }^{5}$ Midland Valley Exploration Ltd., Glasgow, UK.

${ }^{6} \mathrm{CRAAG}$, Algiers, Algeria.

${ }^{7}$ GéoAzur, UMR 6526, Université de Nice Sophia Antipolis, CNRS Valbonne, France.

Copyright 2010 by the American Geophysical Union. 0278-7407/10/2009TC002547
}

$2003 M_{w} 6.8$ Boumerdès-Zemmouri earthquake), at the foot of the continental slope and at the northern sides of basement highs interpreted as stretched continental blocks of the rifted margin. The inherited structures of the margin appear, therefore, to determine this deformation pattern and ultimately the earthquake and tsunami sizes offshore. The complex geometry of the fault system along the Algerian margin suggests a process of initiation of subduction in its central and eastern parts. Citation: Strzerzynski, P., J. Déverchère, A. Cattaneo, A. Domzig, K. Yelles, B. Mercier de Lépinay, N. Babonneau, and A. Boudiaf (2010), Tectonic inheritance and Pliocene-Pleistocene inversion of the Algerian margin around Algiers: Insights from multibeam and seismic reflection data, Tectonics, 29, TC2008, doi:10.1029/2009TC002547.

\section{Introduction}

[2] Inversion tectonics is frequently proposed as an important controlling factor in the structures of collisional belts. Known examples of collisional tectonics are described in the forelands and in the external parts of Tethyan and Himalayan belts [Lemoine et al., 1989] and in Hercynian belts [Vanbrabant et al., 2002]. Few examples of inverted margins are described in presently submerged domains, and most of them are inactive: the NE Atlantic margin represents one of the studied best cases [Jackson and Larsen, 2008; Ritchie et al., 2008]; other examples have also been documented on the Cantabrian domain [Alvarez-Marron et al., 1997]. Only rare examples of active inverted margins are documented worldwide: they are located along the SW and NW Australian margin [Hillis et al., 2008; Keep and Harrowfield, 2008] or in several back arc basins such as in Costa Rica [Brandes et al., 2007], Japan [Tamaki and Honza, 1985], and Tyrrhenian Sea [Billi et al., 2007]. Several mechanisms are proposed to explain the initiation of the shortening at passive margins, for example far-field orogenic stress and ridge push in the case of the NE Atlantic margin [Doré et al., 2008] or changes of the subduction dynamics in the case of back arc basins [Brandes et al., 2007]. Compressive tectonics along passive margins is characterized by the formation of synsedimentary folds and faults, amplification of basement topography [Keep and Harrowfield, 2008] and general uplift of the margin [Holford et al., 2008; Hillis et al., 2008]. In most cases, the 


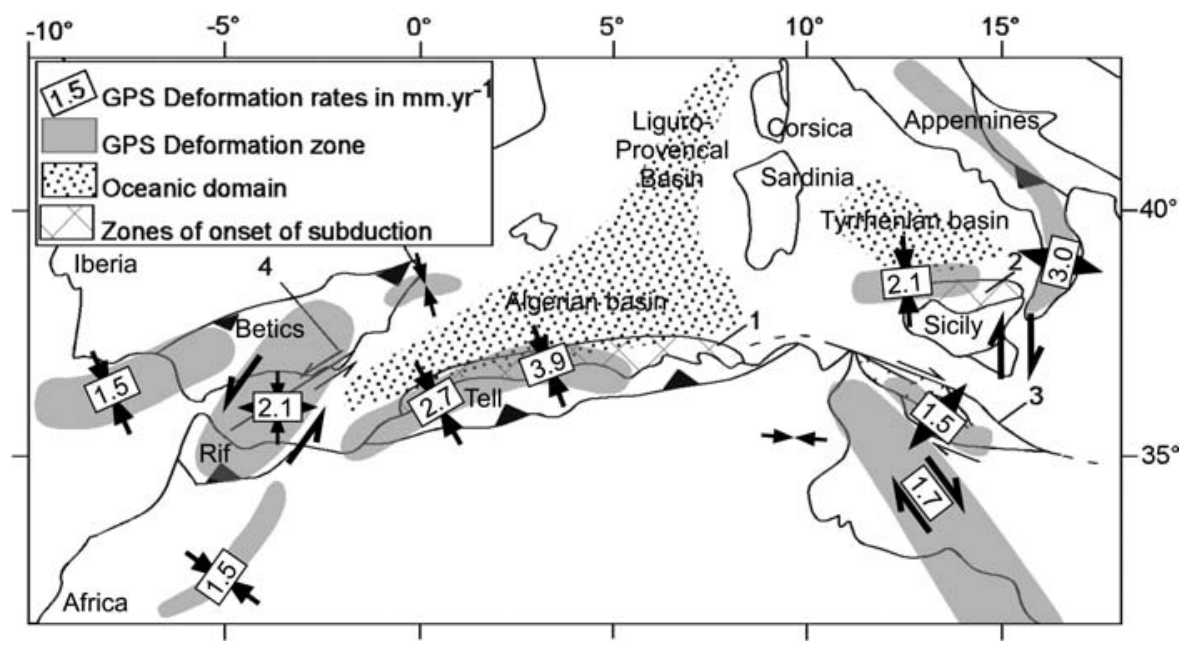

Figure 1. Simplified tectonic sketch of the western and central Mediterranean region, depicting main active fault structures, zones supposed to deform actively today, and parts of Cenozoic back arc basins undergoing incipient southward subduction (modified after Serpelloni et al. [2007]). Numbers refer to mean horizontal strain rates (in $\mathrm{mm} \mathrm{y}^{-1}$ ) assumed using GPS analyses (gray [Stich et al., 2006; Serpelloni et al., 2007]; south Tyrrhenian basin [Serpelloni et al., 2005]) or from geological record of finite deformation at sea (Algerian basin [Kherroubi et al., 2009; Yelles et al., 2009]).

position of compressive structures is controlled by preexisting structures [Hillis et al., 2008; Keep and Harrowfield, 2008].

[3] The study of the active inversion of passive margins is interesting at least for two main reasons. First, active inversion provides important clues on how preexisting structures are reused during inversion and how they help localize deformation. Second, active inversions of these structures can be used to document the early stages of subduction inception [e.g., Toth and Gumis, 1998; House et al., 2002]. The northern margin of the African (Nubia) plate represents an interesting case study in this respect: in the western and central Mediterranean regions (Figure 1), the collision between Nubia and Eurasia has produced the subduction of the Mesogean (Tethyan) slab, the growth of the Maghrebian orogen, and the development of back arc extension. The progressive cessation of subduction across the Maghrebides during the Miocene-Quaternary time span has allowed to resume contractional tectonics at the rear of the orogenic wedge [Faccenna et al., 2004; Déverchère et al., 2005; Billi

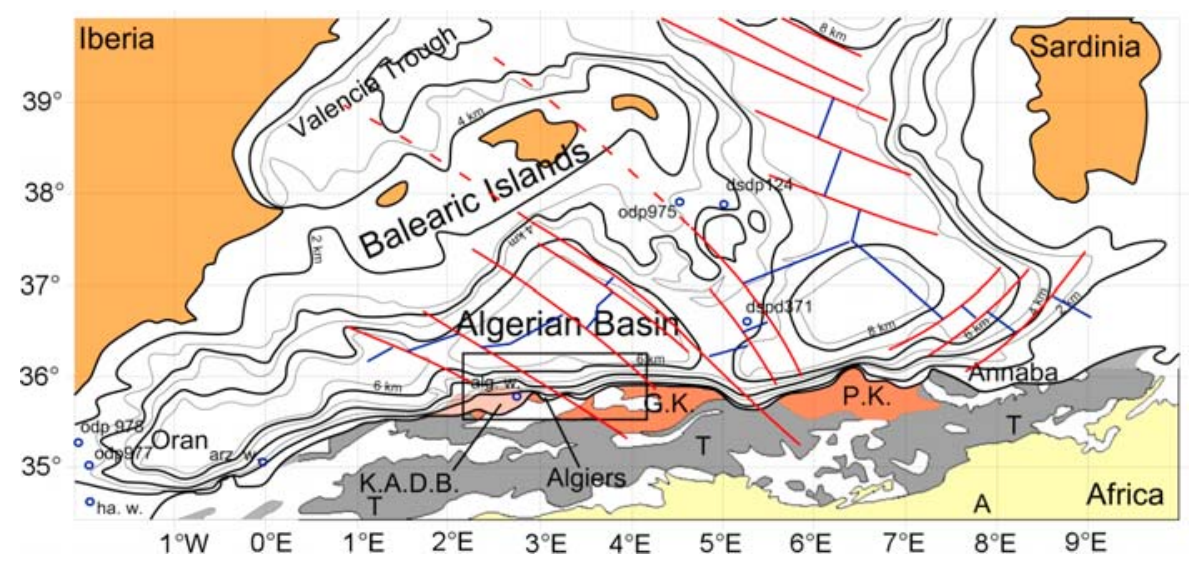

Figure 2. Structural sketch (in map view) of the Algerian basin and the Valencia trough. Onshore portion shows main geologic units of north Algeria: T, Tell unit; A, Atlas; G.K., Grande Kabylie; P.K., Petite Kabylie. Offshore portion is an annotated isobath map of the basement (picture redrawn and interpreted from Figures 2, 4, and 19 of Schettino and Turco [2006]). KADB, Khayr al Din bank with the location of the ODP and DSDP drills. Blue and red lines are the possible position of the spreading centers and the transform faults at the end of the Algerian basins opening, respectively (picture redrawn and interpreted from from Figures 2, 4, and 19 of Schettino and Turco [2006]). 

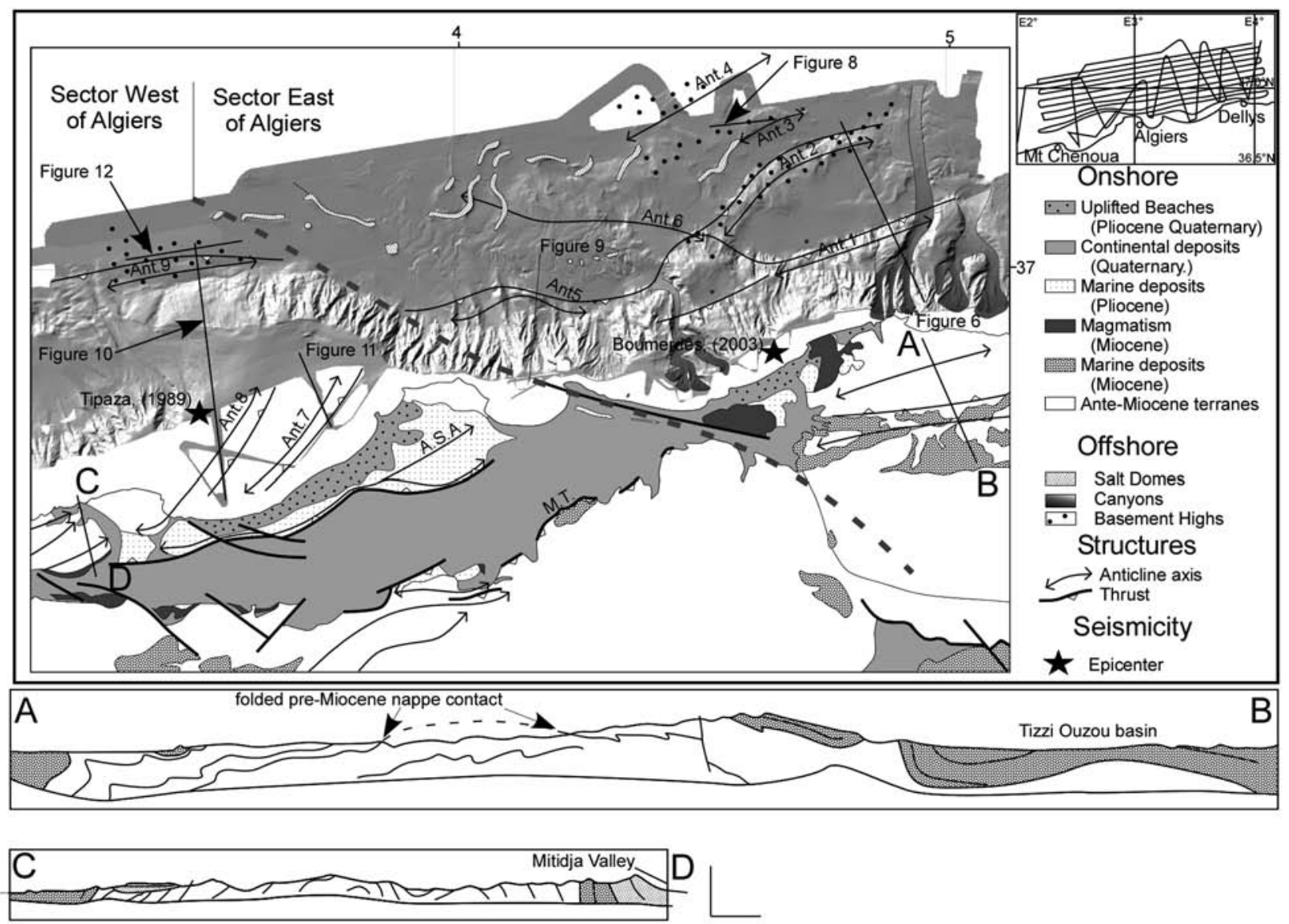

Figure 3. Structural overview of the Algerian margin in the region of Algiers, Algeria. Offshore portion is a structural map plotted above a shaded bathymetric map (MARADJA 2003 cruise). Onshore portion is a tectonic map depicting the Miocene structures (AB and CD are simplified cross sections redrawn after Boudiaf [1996] and Lepvrier [1967], respectively); A.S.A, Algiers Sahel Anticline; M.T., Mitidja Thrust. Stars are epicenter locations of the 2003 Boumerdès earthquake after Ayadi et al. [2003] and of the 1989 earthquake after Meghraoui [1991]. Cross section AB after Bonneton [1977] and cross section CD after Lepvrier [1967]. Inset in the upper right depicts the location map of seismic sections used. The dashed line striking $\mathrm{N} 120^{\circ}$ separates structural sectors west and east of Algiers.

et al., 2007], which implies a contraction of the southern passive margins of the back arc basins of the Tyrrhenian and Algerian seas (Figures 1 and 2). This process is therefore supposed to occur along a significant portion of the presentday plate limit, which raises several important problems relative to the generation of large earthquakes and tsunamis, the Plio-Quaternary evolution of the north African margin and the Mediterranean sea, and the role of inherited structures in the reactivation process. Furthermore, inverted margins have also potentially important places to prospect new oil and gas ressources and/or to assess risk in $\mathrm{CO}_{2}$ sequestration projects [e.g., Cope, 2003; Rogers et al., 2008].

[4] The recent (Pliocene) contractional reactivation of the Algerian margin has been first suggested in the 70s from early geophysical investigations at sea [Auzende et al., 1972, 1975]. Further evidence for compression along the Algerian margin has recently been highlighted using new bathymetry and seismic profiles [Déverchère et al., 2005; Domzig et al.,
2006; Yelles et al., 2009; Kherroubi et al., 2009]. In this study, we focus on the along-strike variations of the style of compressive deformation and on the influence of preexisting structures on the inversion process in order to estimate how compression reuses preexisting structures and when shortening started on the Algerian margin. Our interpretation is based on the comparison of two distinct segments located east and west of Algiers, both onshore and offshore (Figures 2 and 3). The key proxies taken into account in this comparison are the morphology, the sedimentary infill of the basin, and the different (ancient or recent) tectonic structures. A particular attention is paid to the relative timing of tectonic structures and to the lateral changes of the amount of uplift by using various sedimentary markers (Figure 4). To characterize the deformation pattern, we rely on the description of pre-Pliocene structures and their lateral transition from one deformation pattern to another. From this study, we aim to better understand the heterogeneous evo- 


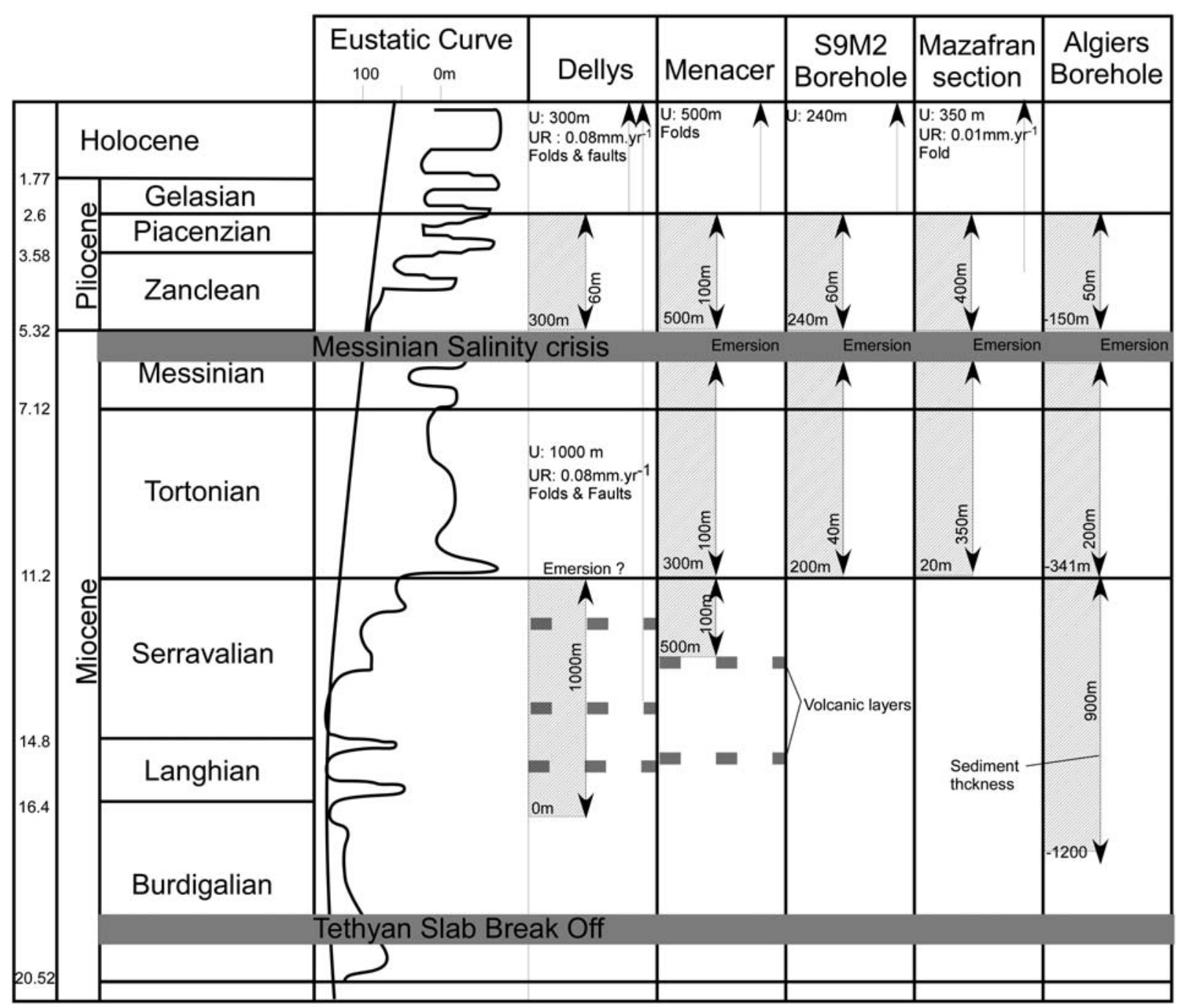

Figure 4. Comparison of the main characteristics of the sedimentary units onshore and offshore. Double arrows represent the thickness of layers. The present-day altitude of the Miocene to Pliocene sedimentary units is shown by horizontal text. Single arrows represent the amount and possible timing of uplift proposed. U, uplift amount; UR, uplift rate. Short-term and long-term eustatic curve after Haq et al. [1987].

lution of the Algerian margin and to provide additional information on the style and type of active structures which have the potential to trigger catastrophic events in the future.

\section{Materials and Methods}

[5] The study area is a $100 \mathrm{~km}$ long stretch of the Algerian margin extending from $3^{\circ} \mathrm{E}$ to $5^{\circ} \mathrm{E}$ in longitude and $36.5^{\circ} \mathrm{N}$ to $37.5^{\circ} \mathrm{N}$ in latitude. The data set consists of swath bathymetry acquired with a Kongsberg Simrad EM-300 multibeam echosounder during the 2003 MARADJA cruise [Déverchère et al., 2005], with a vertical precision ranging laterally from 2 to $10 \mathrm{~m}$. The $50 \mathrm{~m}$ digital elevation model (DEM) constructed with Caraibes(C) software highlights the steep margin slope and basin escarpments (Figure 3). Shading and classification of the DEM were made using ArcGIS Spatial Analyst extension (Figure 5). Additional bathymetric data were provided by two transits of the
Beautemps-Beaupré Research Vessel using a Kongsberg Simrad EM120 multibeam echosounder with a vertical precision of $3 \mathrm{~m}$. A $100 \mathrm{~m}$ DEM covering the most distal part of the study area was processed using this data set.

[6] Multichannel seismic reflection sections were acquired with the following two distinct layouts: (1) 6-channel "fast" seismics with a combination of two double-chamber gas injection air guns shot at intervals of $12 \mathrm{~s}$ and (2) 24channel "high-resolution" seismics acquired with six doublechamber gas injection air guns shot at intervals of $5 \mathrm{~s}$. Seismic section stacking and migration were performed using the public domain seismic processing software package SU (http://www.cwp.mines.edu/cwpcodes/index. html). The processing allowed obtaining good seismic images down to 2-3 s two-way travel time (TWTT) below sea level (bsl; Figures 5-11).

[7] The structural maps in s TWTT of the depth and thickness of the Plio-Quaternary and Messinian Salinity 


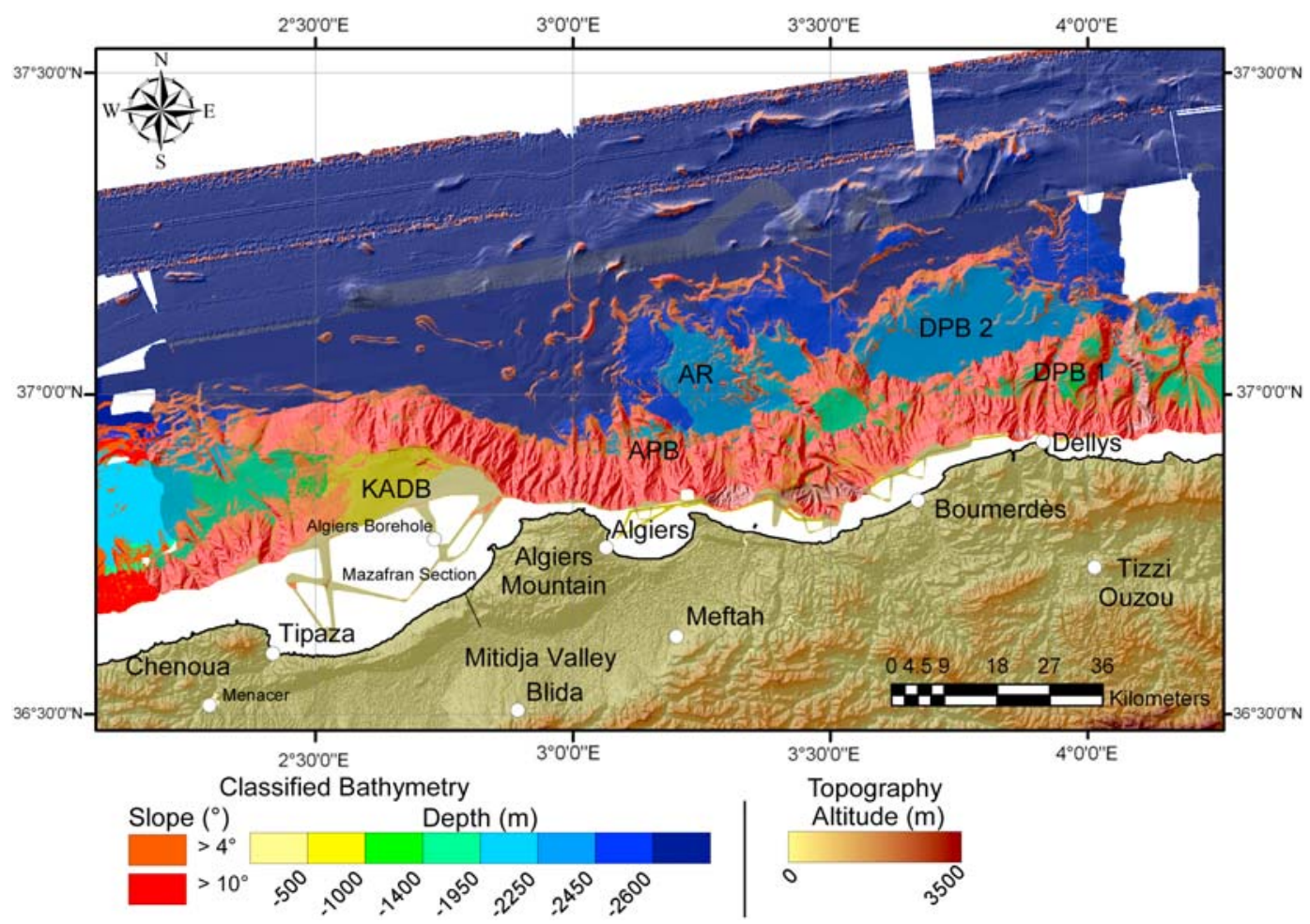

Figure 5. Classification of the bathymetry offshore Algiers. Areas with slope angle greater than $4^{\circ}$ and $10^{\circ}$ are displayed in orange and red, respectively. In areas where the slope angle is lower than $4^{\circ}$, a colorscale bar (yellow to blue) shows the bathymetric changes with more details. AR, Algiers Ridge; APB, Algiers Perched Basin; DPB1 and DPB2, Dellys Perched Basins 1 and 2; KADB, Khayr al Din bank.

Crisis (MSC) unit bases were calculated using the Kingdom Suite software on the basis of the whole MARADJA 2003 seismic survey. Kingdom Suite is also used to flatten some seismic reflectors (Figure 5) and to establish lateral correlations between seismic sections.

\section{Regional Setting}

[8] The Northern boundary of Africa is occupied by the Tell-Atlas Belt that was formed during the Cenozoic collision of Kabylian blocks with the African plate (Figure 2). The collision took place within a slow $\mathrm{N}-\mathrm{S}$ directed convergence between Europe and Africa since the late Cretaceous [Dewey et al., 1989; Rosenbaum and Lister, 2004]. The convergence rate has been about $20 \mathrm{~km} \mathrm{Ma}^{-1}$ between $65 \mathrm{Ma}$ and $20 \mathrm{Ma} \mathrm{BP}$ and then decreased to 1 or $2 \mathrm{~km} \mathrm{Ma}^{-1}$ [Rosenbaum et al., 2002]. A change in the motion of Africa relative to Europe, $\sim 3 \mathrm{Ma}$ ago, is assumed from geological and GPS data [Calais et al., 2003]: the convergence direction could have counterclockwise rotated by about $20^{\circ}$ and became NW-SE at the longitude of the central Algerian margin. The formation of the Tell-Atlas belt and the opening of the Algerian basin are also closely linked to the motion of Iberia relative to Europe: a part of the convergence has been first accommodated along the Pyrenean belt during the Eocene and Oligocene times [Fitzgerald et al., 1999]. The onset of subduction of the Tethyan oceanic domain under the Iberia-Kabylies took place during the
Eocene or the Oligocene [Rosenbaum et al., 2002]. As observed in most convergence systems [e.g., Jolivet et al., 2003; Heuret et al., 2007], the dynamics of the subducted slab controls the evolution of the Tell-Atlas collision belt and allows to recognize two main stages characterized by (1) subduction, slab rollback, and back arc basin opening and (2) collision and slab break off.

\subsection{Steady State Subduction, Slab Rollback, and Opening of the Algerian Basin}

[9] North-dipping subduction of Tethyan oceanic domain took place at the southern boundary of the Kabylian blocks that are assumed to belong to Iberia during Eocene or Oligocene times [Roca et al., 2004]. The Kabylian basement consists of crystalline and metamorphic formations dated from Pan-African to Hercynian orogenies [Peucat et al., 1996]. The southern part of the Kabylian and Chenoua basement is covered by mostly Mesozoic to early Eocene deposits forming the Djurdjura massif in Great Kabylia [Coutelle, 1979; Saadallah et al., 1996]. The occurrence of Eocene inverse flower structures along the southern boundary of the Kabylian blocks suggests that subduction was here oblique with a dextral component [Saadallah et al., 1996]. As a consequence of slab rollback [Jolivet and Faccenna, 2000], the Algerian basin formed in a back arc position [Roca et al., 2004]. Extension started probably during the late Oligocene or early Miocene times [Dewey et al., 1989; Rosenbaum and 

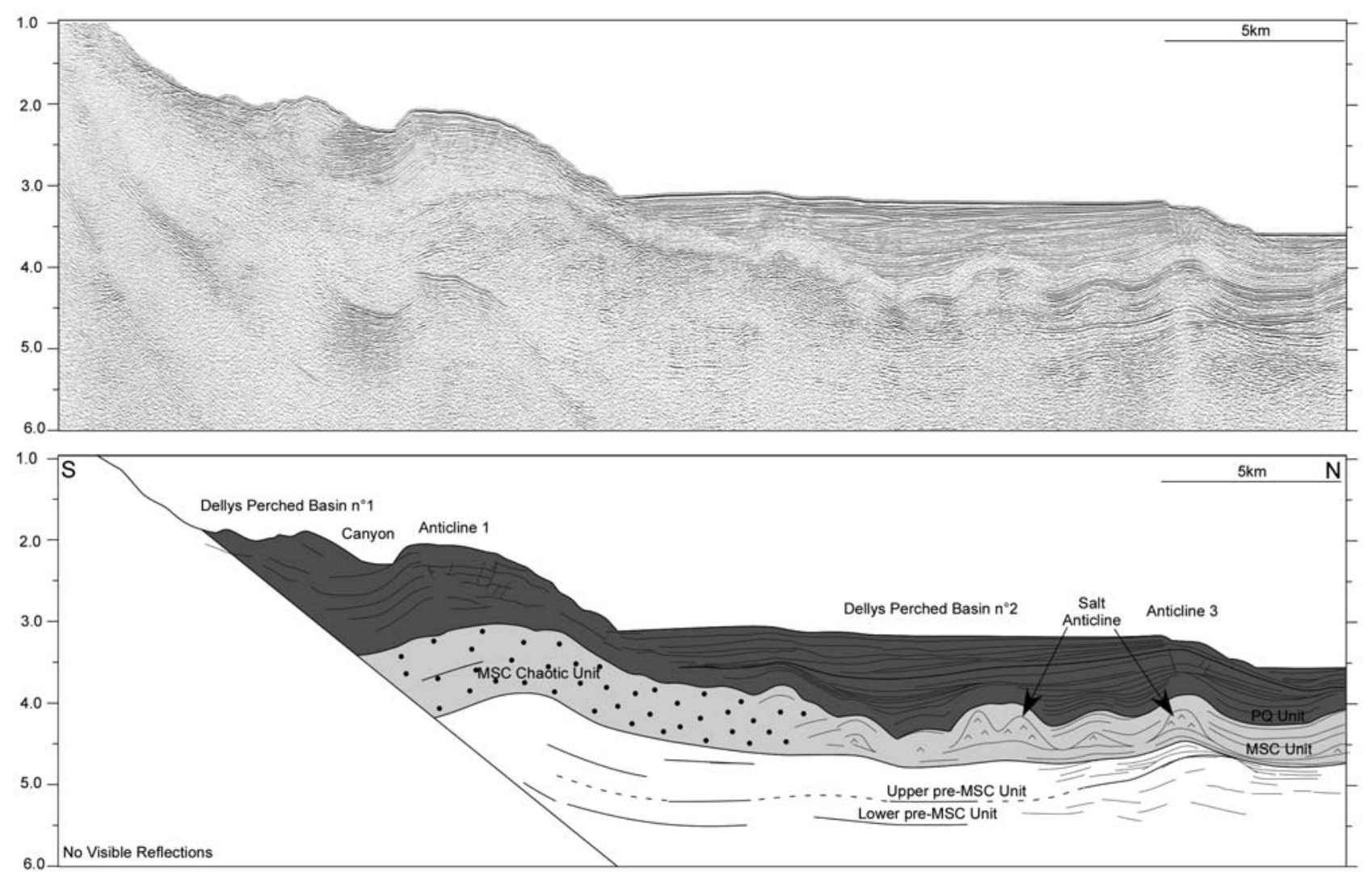

Figure 6. Seismic section and line drawing of a representative six-channel seismic line across the Algerian margin, east of Algiers, off Dellys, crossing the Sebaou canyon on the slope (location in Figure 3). Vertical scale is in two-way travel times (TWTTs) in s. Vertical exaggeration is $3 \times$ at the seafloor.

Lister, 2004; Schettino and Turco, 2006]. This is evidenced in the Grande Kabylies by the occurrence of ductile extension dated at $25 \mathrm{Ma}$ [Monié et al., 1984; Saadallah and Caby, 1996] followed by the deposition of a detritic series called "Oligo-Miocene Kabyle" [Coutelle, 1979] of Late Lutetian to early Miocene age [Rivière et al., 1977].

[10] In the Algerian basin, evidence for extension is provided by the occurrence of basement highs highlighted by seismic sections and interpreted as heads of tilted blocks [Cope, 2003; Mauffret, 2007]. The opening of the Algerian basin is associated with the formation of oceanic crust as evidenced by recent wide-angle seismic results [Pesquer et $a l ., 2008]$. Shifts of the magnetic anomalies of the Algerian basin lead to recognize NW-SE strike-slip faults separating the Kabylian units into four rigid blocks [Schettino and Turco, 2006]. A dextral offset of 20 to $48 \mathrm{~km}$ along a similar NW-SE fault has been estimated between Ibiza and Majorca (Figure 2) [Maillard and Mauffret, 1999; Schettino and Turco, 2006].

\subsection{Collision and Slab Break Off}

[11] The Tethyan slab break off is assumed to sign the end of the Algerian basin spreading [Carminati et al., 1998; Maury et al., 2000; Rosenbaum and Lister, 2004; Schettino and Turco, 2006]. Such event is believed to occur during the
Burdigalian ( 20-16 Ma BP) and is evidenced by a change of chemistry of volcanism along the Algerian margin at $\sim 19 \mathrm{Ma}$ [Maury et al., 2000].

[12] The collision of Kabylian blocks with Africa is apparently almost synchronous to slab break off: in Great Kabylia, collision is associated with the emplacement of Tellian nappes to the north directly above the Oligo-Miocene Kabyle deposits [Bouillin, 1986] and to the south above the Atlas foreland (Figure 2) [Bracene and Frizon de Lamotte, 2002]. These nappes were next sealed in late Burdigalian to Tortonian times by marine deposits [Raymond, 1976]. Deformations consistent with a NW-SE direction of shortening have been recognized in these Burdigalian to Tortonian deposits [Glangeaud, 1952; Raymond, 1976; Aïté and Gélard, 1997]. Near the cities of Dellys and Tizzi Ouzou (Figure 5), synsedimentary faults compatible with a NNWSSE direction of extension are described within Burdigalian to Serravalian deposits [Aïté and Gélard, 1997]. This observation suggests a possible period of extension between the emplacement of the nappes and the onset of the late Miocene compression.

[13] In the Algerian basin, ocean spreading and postslab break off period are uneasy to decipher in absence of deep seismic reflection profiles and/or deep boreholes. The postrift evolution of the Algerian basin is characterized by the 


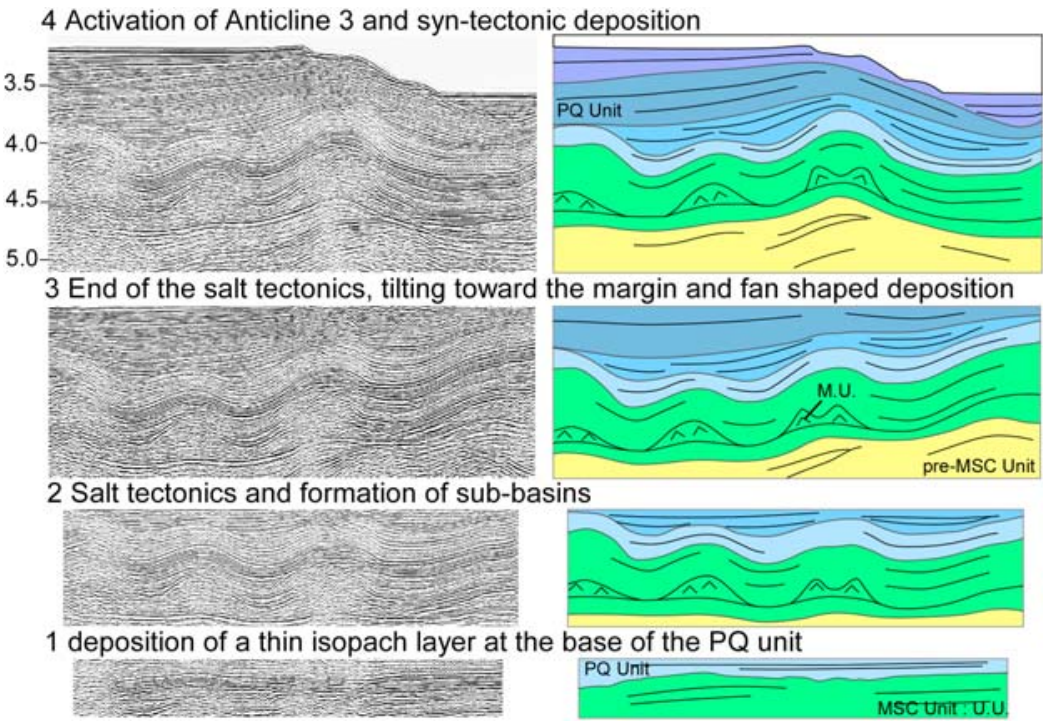

Figure 7. Four steps of Plio-Quaternary evolution of Anticline 3 (see Figures 5 and 3 for location) using "flatten" and "unflatten" functions of Kingdom Suite software. The evolution of the area is characterized by the formation of a salt anticline prior to the onset of tectonics along Anticline 3 . Vertical exaggeration is $3 \times$ at the seafloor.

deposition of a more than $2 \mathrm{~km}$ thick Miocene series onlapping and progressively concealing the basement highs [Cope, 2003]. As a consequence, the marked large lateral changes of thickness of the Miocene deposits induced the formation of drape anticlines in the Miocene series [Cope, 2003]. In the deep basin, there is no evidence of Miocene shortening as observed onland [Cope, 2003; Mauffret, 2007].

[14] The end of the Miocene period was characterized by the Messinian Salinity Crisis (MSC), which culminated with a major Mediterranean sea level fall [Ryan and Cita, 1978; Clauzon, 1996] responsible for the emersion and the erosion of the upper part of continental margins. In the deep basin, this event is associated with the deposition of an evaporitic unit [Hsü et al., 1978]. The Pliocene sea level rise at 5.3 Ma caused a submergence of the subaerially exposed and eroded margins. Then, Gilbert deltas prograded into the Messinian rias [Rubino et al., 2007] (Figure 3). These deposits have been dated from Early Pliocene time in the Mitidja valley
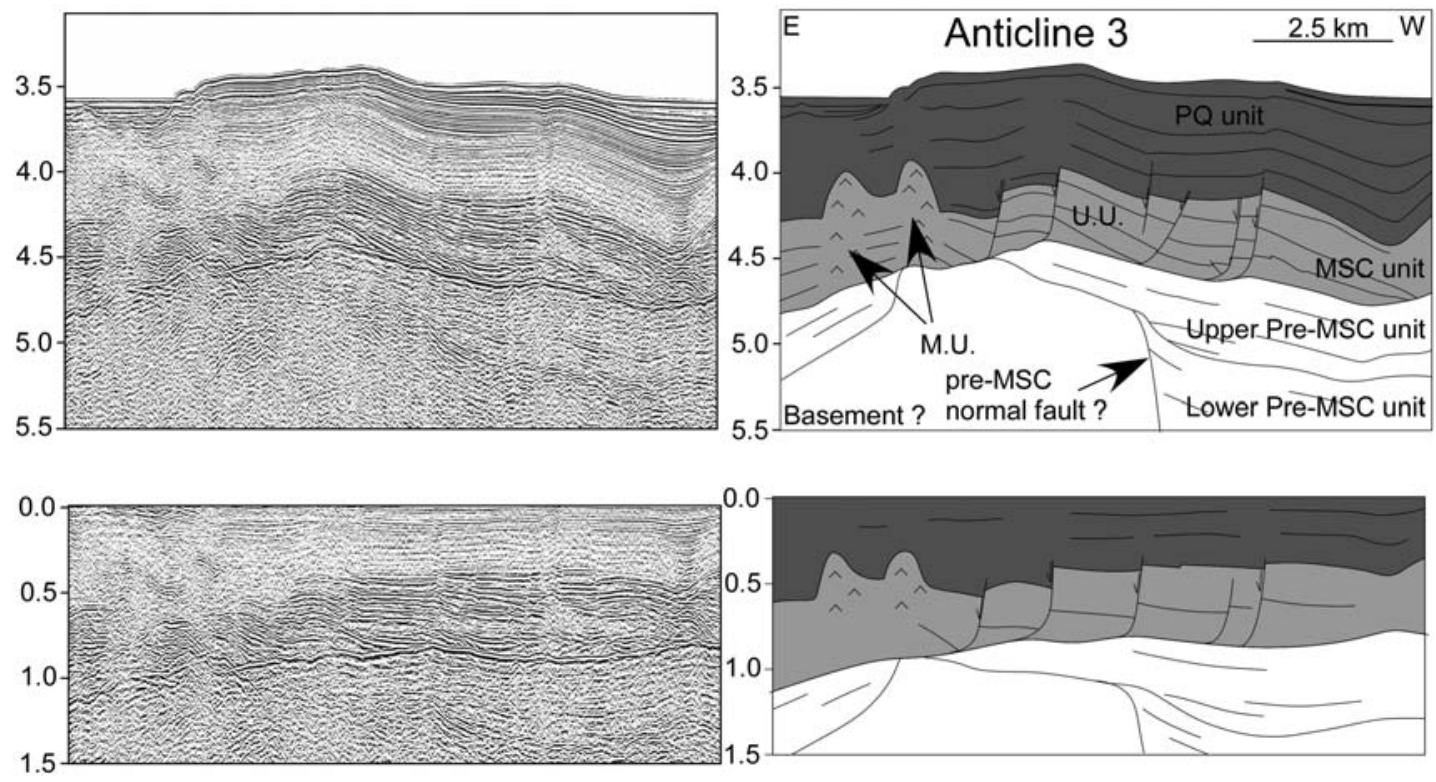

Figure 8. Seismic section and interpretation of a six-track seismic line located east of Algiers (location in Figure 3). Vertical exaggeration is $3 \times$ at the seafloor. 


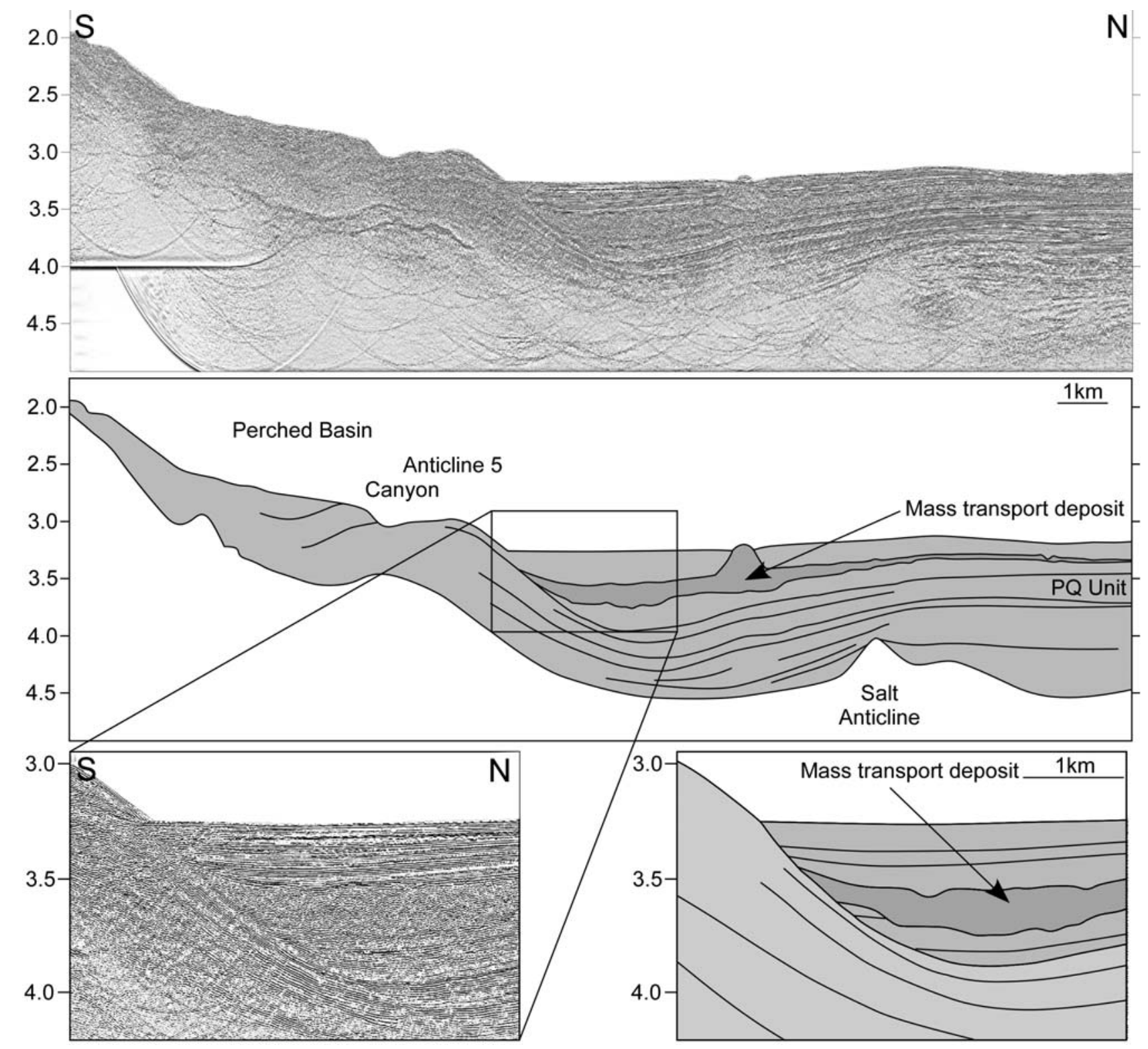

Figure 9. Seismic section and line drawing of a profile located north of Algiers (location in Figure 3). Vertical exaggeration is $3 \times$ at the seafloor.

[Yassini, 1975]. In its present-day position, the transition between oceanic and continental deposits is located at $\sim 200 \mathrm{~m}$ above the present-day sea level, suggesting that a significant uplift occurred since the filling of the Messinian rias [Rubino et al., 2007].

[15] Within the Plio-Quaternary unit, compressive deformations are recognized onshore close to Algiers as expressed by the folding of the Early Pliocene Mitidja deposits at its southern boundary and of the Sahel anticline near the coastline (Figure 3) [Boudiaf, 1996; Meghraoui, 1991]. East of Algiers, deformation is also evidenced by the eastward migration of the Isser River bed and uplifted beaches [Boudiaf et al., 1998]. The orientation of PlioQuaternary structures is compatible with a NW-SE direction of compression, suggesting that there is a continuum between
Tortonian and Plio-Quaternary strain fields. In the deep basin, Plio-Quaternary deformations have also been recognized [Auzende et al., 1972; Déverchère et al., 2005; Domzig et al., 2006; Mauffret, 2007]. We provide below (in sections 4 and 5) further evidence for the development of these peculiar structures.

\subsection{Present-Day Tectonic Activity of the Study Area}

[16] The Algiers area is one of the most seismically active area of the western Mediterranean domain and is characterized by several earthquakes with magnitude up to $M_{w} 7^{1 / 2}$ [Rothé, 1950]. Earthquakes are common both onshore and offshore. We focus here on two recent earthquakes: the 

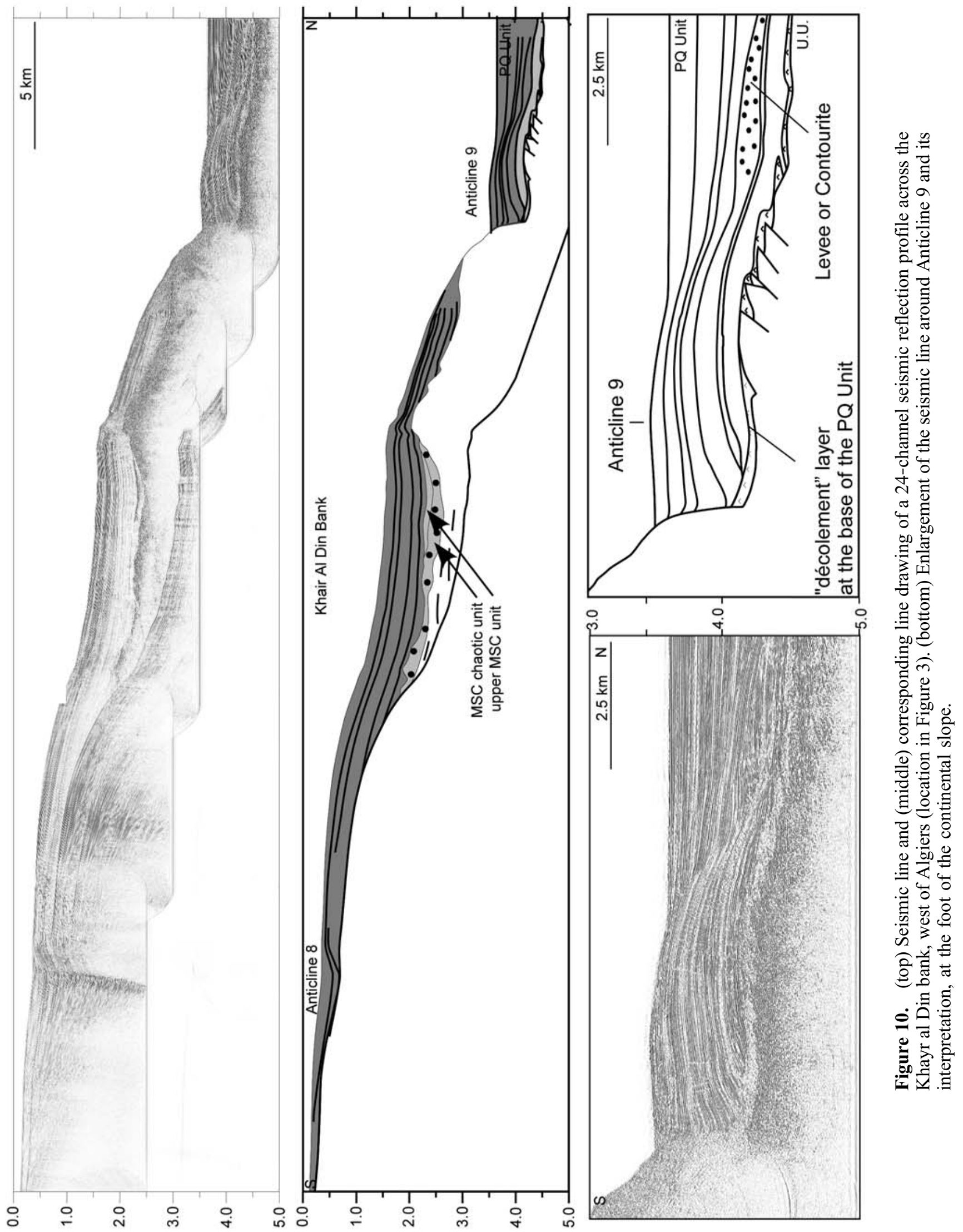

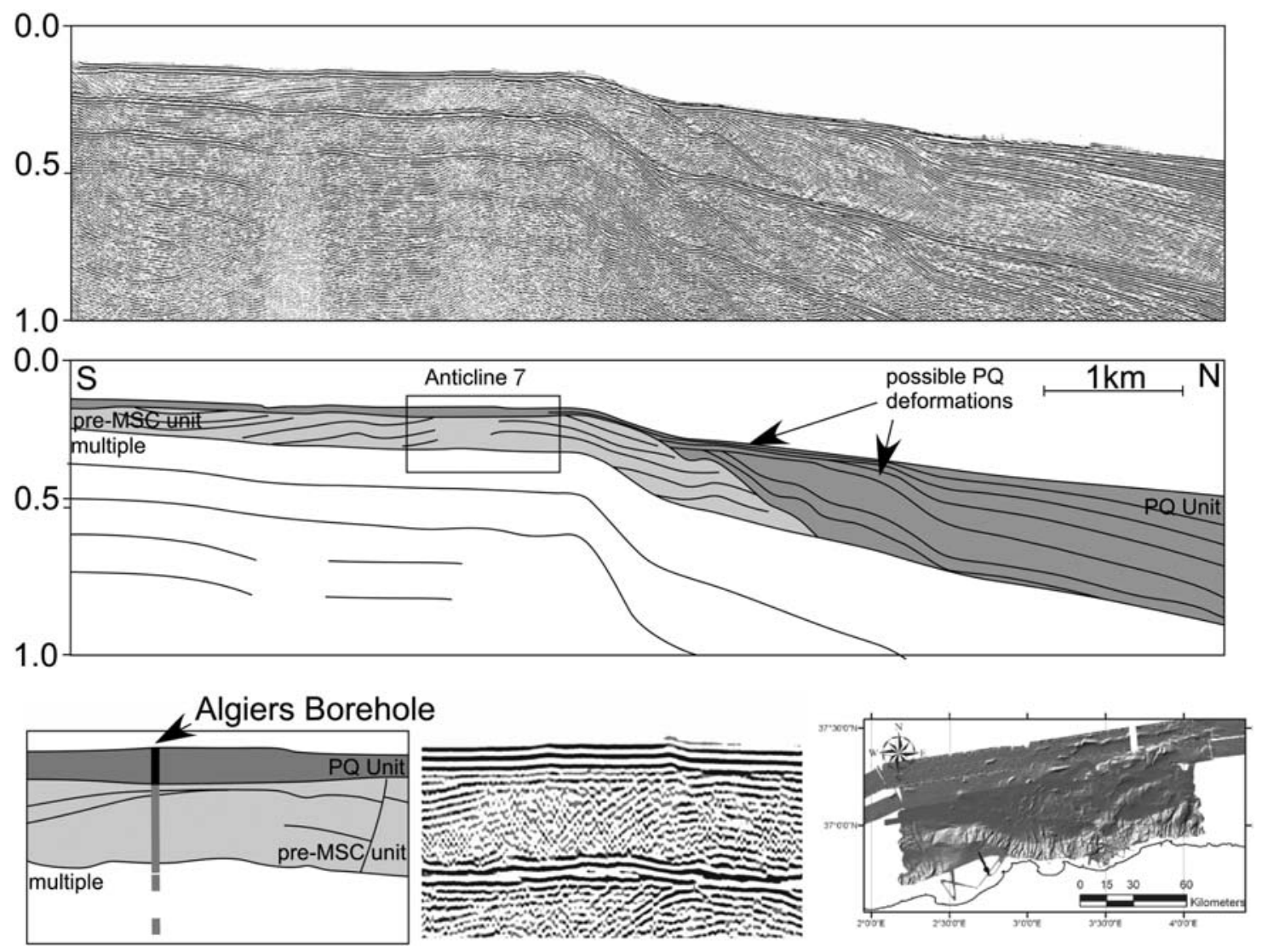

Figure 11. Line drawing of a 24-channel seismic reflection profile across the Khair al Din bank, west of Algiers (location in Figure 3). Age of the formation on seismic section is given by the projection of the Algiers borehole [Burollet et al., 1978] on the seismic section. Vertical exaggeration is $3 \times$ at the seafloor.

Boumerdès (2003) and the Tipaza (1989) earthquakes (Figure 3).

[17] The most destructive earthquake of the studied area is the $2003 M_{w} 6.9$ Boumerdès earthquake located close to the shoreline [Bounif et al., 2004; Ayadi et al., 2003, 2008]. Evidence for coseismic coastal uplift was observed between Boumerdès and Dellys with a maximum value of $0.7 \pm$ $0.15 \mathrm{~m}$ near Boumerdès [Meghraoui et al., 2004]. Rupture took place at depths ranging between 5 to $15 \mathrm{~km}$ and along a $55 \mathrm{~km}$ long south-dipping thrust, striking about $\mathrm{N} 70^{\circ} \mathrm{E}$ [Delouis et al., 2004]. The aftershock sequence was characterized by thrust events between Boumerdès and Dellys and strike-slip events west of Boumerdès along a supposed $\mathrm{N} 100^{\circ}$ to $\mathrm{N} 120^{\circ}$ vertical structure located near the shoreline (Figure 3) [Braunmiller and Bernardi, 2005; Ayadi et al., 2008]. Fourteen years before the Boumerdès earthquake, the Tipaza event (Ms 5.7) occurred in the western part of the study area, on 28 October 1989. Its epicenter was located at the base of the Chenoua massif (Figure 3) close to the shoreline. The focal mechanism indicates that the rupture took place on a $\mathrm{N} 60^{\circ}$ to $\mathrm{N} 70^{\circ}$ trending fault dipping with an angle of $60^{\circ}$ to the south [Meghraoui, 1991; Bounif et al., 2003]. Coseismic surface breaks consisting of cracks and fissures with a maximum displacement of $0.07 \mathrm{~m}$ have been mapped on the southern face of the Chenoua massif
[Meghraoui, 1991]. Aftershocks were widely distributed offshore and displayed an ENE-WSW to NE-SW trend, reaching depths down to $20 \mathrm{~km}$ [e.g., Meghraoui, 1991].

\section{Miocene to Quaternary Evolution Onshore}

\subsection{Sedimentary Evolution East and West of Algiers}

[18] Onshore marine sedimentation is documented from Burdigalian to Tortonian and during Pliocene times. Some differences are observed east and west of Algiers, especially regarding the altitude and thickness of the deposits (Figure 4).

[19] East of Algiers, marine deposits of Miocene age are recognized between the shoreline and the city of Tizzi Ouzou. On the basis of micropaleontological and volcanic dating, a Burdigalian to Serravalian age can be proposed for these series (Figure 4) [Raymond, 1976; Belanteur et al., 1995]. Near the shoreline, they are $1000 \mathrm{~m}$ thick. After a probable emersion during the Tortonian and Messinian times, sedimentation started again during Pliocene time near the city of Dellys. In the Tizzi Ouzou basin, Pliocene formations are absent, suggesting that the last sea transgression in the Tizzi Ouzou basin occurred during Burdigalian to Serravalian times. 
[20] West of Algiers, various sections located near the city of Menacer provide an overview of the sedimentary series of the Mitidja valley (Figure 4). Here, the Miocene marine sedimentation is characterized by strong lateral changes from one place to another. Near the southern boundary of the Mitidja valley, Burdigalian to Serravalian deposits form 150 to $300 \mathrm{~m}$ thick series [Bonneton, 1977]. Toward the west, these deposits thin and are absent around the city of Menacer (Figure 4, see Bonneton [1977] for a comparison). Here, we note the absence of Langhian and Serravalian formations. Fourty meters thick Tortonian marls and sandstones overlie directly the basement, Burdigalian conglomerates and clastic deposits and/or volcanics [Yassini, 1975; Bellon et al., 1977]. Tortonian deposits are also observed in the heart of the Algiers Sahel anticline along the Mazafran section [Yassini, 1975], where they are $350 \mathrm{~m}$ thick. Pliocene marine deposits are recognized in many places of the Mitidja valley. However, in absence of borehole in the middle of the Mitidja valley, thicknesses are poorly constrained: a maximum thickness of up to $400 \mathrm{~m}$ has been recognized in the Mazafran section (Figure 4) [Yassini, 1975].

\subsection{Miocene to Present-Day Structures Onshore}

[21] East of Algiers, the Miocene formations are folded: a $20 \mathrm{~km}$ wide anticline, called thereafter the Dellys Anticline (Figure 3), culminates at $600 \mathrm{~m}$ height with a $\mathrm{N}^{\circ}$ trend and is visible near the coastline, roughly parallel to a similar scale syncline located around the city of Tizzi Ouzou (Figure 3) [Raymond, 1976]. South of Tizzi Ouzou, folding and southward thrusting are inferred from the shift of cover units [Raymond, 1976] (Figure 3).

[22] Near Dellys, there is no evidence for faulting at the surface; however, the asymmetry of folds suggests that blind thrust faults dipping to the south control at least part of the deformation (Figure 3). Near the Dellys Anticline hinge, marine sediments of Pliocene age are uplifted up to $300 \mathrm{~m}$. Assuming a $+70 \mathrm{~m}$ sea level during Pliocene time, $230 \mathrm{~m}$ of uplift is estimated for the Pliocene to present-day time span (Figure 4). Near the shoreline, beach deposits of unknown age are uplifted of up to $50 \mathrm{~m}$ [De Lamothe, 1911; Raymond, 1976], suggesting that uplift was active during recent times. Immediately to the west, two successive changes of the Isser bed are related to Plio-Quaternary tectonics near the shoreline (Figure 3) [Boudiaf et al., 1998]. Along Anticline 1, the $1000 \mathrm{~m}$ thick Miocene formation is now above sea level. During the Burdigalian and Serravalian time span, sea level was about $100 \mathrm{~m}$ higher than today (Figure 4). This observation therefore suggests that Miocene formations have recorded at least $900 \mathrm{~m}$ of uplift since their deposition during Tortonian time. Assuming an age of 11.6 Ma and 2.6 Ma BP for the top of the Serravalian and of the Piacenzian, respectively, we calculate similar mean uplifted rates of $0.08 \pm 0.02 \mathrm{~mm} \mathrm{y}^{-1}$ since the Serravalian and Piacenzian times for the area east of Algiers.

[23] West of Algiers, Miocene and Pliocene deposits are also folded. The main structure in this area is the $20 \mathrm{~km}$ wide and $80 \mathrm{~km}$ long syncline located beneath the Mitidja valley (Figure 3). The Mitidja valley consists of a basin filled by Tortonian, Pliocene and Quaternary deposits which are hiding the contact between the internal units and the Tellian domain (Figure 3). This basin is bounded to the north by the Sahel anticline and to the south by a more complex structure forming the contact with the Blida Atlas [Bonneton, 1977].

[24] The Algiers Sahel anticline is a $165^{\circ}$ trending and $60 \mathrm{~km}$ long anticline that has been extensively studied in the past [De Lamothe, 1911; Glangeaud, 1952; Meghraoui, 1991; Boudiaf, 1996]. The structure is limited by two basement massifs: the Chenoua Massif to the west and the Algiers massif to the east (Figure 5). Between these metamorphic bodies, Tortonian to Pliocene deposits are folded. Asymmetry of the fold and seismicity are compatible with a north-dipping blind thrust controlling the growth of the fold. On the southern boundaries of the Mitidja valley, the imbrications of Tellian, Miocene and Pliocene units form a complex structure. There, the folding of the Miocene sediments is mostly controlled by south-dipping thrusts [Bonneton, 1977] (Figure 3).

[25] Along the Algiers Sahel Anticline, Pliocene deposits are $400 \mathrm{~m}$ thick and the top of the formation is located at $300 \mathrm{~m}$ height (Figure 4). Considering a mean sea level $70 \mathrm{~m}$ higher than today during Pliocene time, an uplift ranging between 230 and $330 \mathrm{~m}$ is calculated along the hinge of the anticline. Using a Piacenzian age for the youngest deposits of the Algiers Sahel, a $0.1 \pm 0.02 \mathrm{~mm} \mathrm{y}^{-1}$ uplift rate is calculated for the Algiers Sahel anticline since Pliocene time. Numerous levels of uplifted beach deposits have been described along the northern flank of the Algiers Sahel anticline [De Lamothe, 1911; Glangeaud, 1952]. One level, located at $20 \mathrm{~m}$ high, has been dated and is associated to the MIS 5 Stage which occurred at 135,000 years BP [Stearn and Thurber, 1965], suggesting that uplift occurred during recent times. Considering a $+5 \mathrm{~m}$ high sea level for the MIS 5 stage, $13 \mathrm{~m}$ of uplift and $0.1 \pm 0.02 \mathrm{~mm} \mathrm{y}^{-1}$ are inferred since 135,000 years. The age of onset of folding is difficult to estimate: in map view, changes of Pliocene deposits are spatially correlated with the orientation and the position of the anticline hinge, suggesting that the anticline was active prior to emersion. This interpretation is also compatible with the occurrence of uplifted beach deposits directly covering the basement rocks on the Algiers massif at $350 \mathrm{~m}$ in elevation. Here, beach deposits are located around the summit of the massif, suggesting that these deposits mark the emersion of the Algiers massif during deformation. Assuming a constant uplift rate of $0.1 \pm 0.02 \mathrm{~mm} \mathrm{y}^{-1}$ prior to the emersion of the Sahel anticline, we propose a $3.5 \pm 0.5 \mathrm{Ma}$ age for the emersion of the Algiers massif. However, we cannot conclude if the Algiers Sahel anticline was active during the Tortonian and the Messinian in absence of precise estimate of the changes of thickness of the Tortonian deposits.

[26] Along the southern boundary of the Mitidja valley, the folding and faulting of the Miocene formations may have occurred during the Tortonian and/or the Messinian as the Pliocene deposits are postdating the formation of folding in many locations [Bonneton, 1977] (Figure 3). Contractional tectonics are in many places ending during Pliocene time. However, Pliocene deposits are also folded and deformation is 
Table 1. Main Characteristics and Geometrical Relationships of the Seismic Units of the Algerian Margin and Deep Basin

\begin{tabular}{|c|c|c|c|c|}
\hline Main Unit & Subunit & Seismic Expression & Geometrical Characteristics & Short Name \\
\hline PQ unit & & $\begin{array}{l}\text { High-frequency, } \\
\text { midamplitude reflections }\end{array}$ & $\begin{array}{l}\text { Above MSC, pre-MSC deposits } \\
\text { and basement }\end{array}$ & PQ \\
\hline MSC unit & Clastic horizon & $\begin{array}{l}\text { Chaotic more or less } \\
\text { transparent unit }\end{array}$ & $\begin{array}{l}\text { Complex relationship with other } \\
\text { MSC depositional units }\end{array}$ & $\mathrm{CU}$ \\
\hline MSC unit & Upper MSC horizon & $\begin{array}{c}\text { High-frequency, } \\
\text { high-amplitude reflections }\end{array}$ & $\begin{array}{l}\text { Above MSC mobile horizon, } \\
\text { beneath the Plio- Quaternary unit }\end{array}$ & UU \\
\hline MSC unit & MSC Mobile horizon & Transparent unit. & $\begin{array}{l}\text { Between pre-MSC unit and } \\
\text { Upper MSC horizon }\end{array}$ & MU \\
\hline Pre-MSC unit & & $\begin{array}{l}\text { Low-frequency, high } \\
\text { continuity reflections }\end{array}$ & $\begin{array}{l}\text { Beneath MU, above } \\
\text { pre-MSC deposits }\end{array}$ & pre-MSC U \\
\hline Basement & & Acoustic basement & $\begin{array}{l}\text { Beneath pre-MSC, MSC, } \\
\text { and PQ units }\end{array}$ & Basement \\
\hline
\end{tabular}

associated with south-dipping thrusts on the eastern side of the Mitidja Valley near Meftah city [Bonneton, 1977] (Figure 3).

[27] To conclude on the Miocene to present evolution on land near the shoreline, we observe several similarities and differences east and west of Algiers. Similarities concern the timing of the deformation and the deformation rates. Tectonic styles are also similar as both north- and south-verging structures occur east and west of Algiers. Differences concern mostly the position of structures relative to the shoreline: east of Algiers, uplift along Dellys Anticline is recorded since the Tortonian, whereas west of Algiers, subsidence is recorded in the Mitidja Valley during the Tortonian. This observation is consistent with the difference in the mean vertical height of the blocks of the Internal Zones: west of Algiers, the Khayr Al Din bank [Yelles et al., 2009] is mostly under water, whereas east of Algiers, the basement of the Grande Kabylies is uplifted [Boudiaf et al., 1999].

\section{Miocene to Quaternary Evolution Offshore}

\subsection{Overall Physiography}

[28] The Algerian margin shows significant morphological differences east and west of Algiers. East of Algiers, the maximum margin width is $20 \mathrm{~km}$ with a narrow continental shelf and a continental slope showing a main $\mathrm{N} 60-70^{\circ}$ strike and a slope angle greater than $4^{\circ}$ (Figure 5). The continental slope is deeply incised by numerous canyons and gullies, as for instance the Algiers and the Dellys canyons (Figure 5), and marked by seafloor scarps of various length, width and strike separating small perched basins in a present water depth range of 1500 to $2500 \mathrm{~m}$ [Déverchère et al., 2005; Domzig et al., 2006; Dan et al., 2009, 2010]. East of the Algiers canyon, two main perched basins have been identified [Déverchère et al., 2005]: here, we refer to them as the Dellys perched basins 1 and 2 (Figure 5).

[29] West of the Algiers canyon, we recognize another perched basin strongly incised by gullies, called the Algiers perched basin (Figure 5). The deep basin west of the Algiers canyon is occupied by the Algiers ridge (Figure 5). West of Algiers (Figure 5), the width of the continental shelf and the continental slope is up to $45 \mathrm{~km}$, including a wider continental shelf. In this western area, from east to west, the continental slope strikes from $\mathrm{N} 140^{\circ}$ to $\mathrm{N} 70^{\circ}$. It forms a large submarine high, named the Khayr al Din bank [Domzig et al., 2006; Yelles et al., 2009] hereafter referred as KADB (Figure 5).

\subsection{Seismic Units East and West of Algiers}

[30] Offshore, three main units overlie the acoustic basement. They consist from bottom to top of a pre-MSC sequence dating back probably to early Miocene time [e.g., Réhault et al., 1984; Cope, 2003; Déverchère et al., 2005; Mauffret, 2007], the MSC unit and a Pliocene-Quaternary unit (PQ) (Table 1).

[31] In the deep basin, the pre-MSC unit is characterized by low-frequency and low-amplitude seismic reflections (Figures 6 and 8 and Table 1). At places, an unconformity is observed into the pre-MSC unit near 5.2-5.5 s TWTT: it separates a lower unit that forms large symmetrical anticlines and an upper unit that seals the anticlines and fills some subbasins. Following Cope [2003], we interpret these large and symmetrical anticlines as drape anticlines. On the MARADJA seismic lines, the base of the pre-MSC units is never visible in the deep basin because reflections are visible down to $5.5 \mathrm{~s}$ TWTT at the most, i.e., above the basement top. According to previous studies, this basement consists of an high amplitude, chaotic unit (Figure 8) [Roca et al., 2004; Mauffret, 2007]. Following Cope [2003] and Mauffret [2007], we infer an Aquitanian to lower Messinian age for the pre-MSC unit.

[32] The MSC unit is composed of two different horizons (Table 1): the upper one is characterized by high-amplitude seismic reflectors that contrast with the low-amplitude reflections of the base of the Plio-Quaternary unit. Its thickness ranges between 0.3 and $0.6 \mathrm{~s}$ TWTT (Table 2). The upper horizon overlies a discontinuous and transparent layer. The thickness of this transparent layer reaches up to $1.5 \mathrm{~s}$ TWTT, but it is absent at places (Table 2). Where the transparent horizon is thicker, it forms some discontinuous anticline and dome structures that are per places intrusive within the Plio-Quaternary unit. Where the transparent unit is absent, the upper MSC horizon is directly overlying the pre-MSC unit. Seismic unconformities are frequently observed, showing that the upper layer is downlapping the pre-MSC unit. The tilting of the upper MSC horizon is in this case accommodated by normal motion along faults. Anticlines and domes have been interpreted as diapiric structures related to the Messinian salt. Normal faulting, absence of transparent horizon and downlap of the Upper MSC unit have been interpreted as evidence for salt migration [Réhault et al., 1984; Gaullier et al., 2000; Sage 
Table 2. Depth of the Base and Thickness of the Pre-MSC, MSC and PQ Units East, North, and West of Algiers

\begin{tabular}{lccc}
\hline & \multicolumn{3}{c}{ Seismic Units in the Deep Basin (s TWTT) } \\
\cline { 2 - 4 } Number & East of Algiers & North of Algiers & West of Algiers \\
\hline PQ unit & & & \\
$\quad$ Depth & $3.5-4.5$ & $4.0-5.0$ & $3.5-4.5$ \\
$\quad$ Thickness & $0.6-1.0$ & $0.0-1.4$ & $0.2-0.6$ \\
MSC unit & & & \\
Depth & $4.4-4.8$ & $5.0-5.4$ & $4.0-4.8$ \\
Thickness & $0.2-0.6$ & $0.2-1.4$ & $0.2-0.4$ \\
\hline
\end{tabular}

et al., 2005; Lofi et al., 2005]. On the continental shelf and on the upper portion of the continental slope, the MSC unit depicts lateral changes: at the foot of the continental slope, it turns into a 0.3 to $0.7 \mathrm{~s}$ TWTT chaotic body (Figure 6), whereas MSC deposits are absent on the continental shelf (Figures 10 and 11): there, the Plio-Quaternary unit directly overlies pre-MSC unit and unconformities (downlaps and toplaps) are observed between the two units. Such type of lateral changes of the MSC deposits has been widely observed on other Mediterranean margins. It has been interpreted as the seismic expression of subaerial erosion of the continental shelf and continental domain, responsible for deposition of deep detrital fans at the foot of the continental slope during the MSC [e.g., Sage et al., 2005; Lofi et al., 2005], occurring most likely during the Messinian major sea level fall between 5.33 and 5.6 Ma BP [Gautier et al., 1994].

[33] The Pliocene-Quaternary unit is characterized by high-frequency and mid- to low-amplitude reflections (Table 1). In the deep basin, the amplitude of seismic reflectors progressively decreases from the top to the base of the unit as generally observed in the Mediterranean basin [e.g., Réhault et al., 1984]. Unit thickness ranges between 0.5 and $1.2 \mathrm{~s}$ TWTT (Table 2). On the continental slope and on the continental shelf, no decrease of amplitude is observed and thickness ranges between 0 and $1 \mathrm{~s}$ TWTT (Table 2). In the KADB, the Algiers bay and north of Boumerdès, we recognize a peculiar unit located between a 0 to $50 \mathrm{~m}$ thick Quaternary unit and the acoustic basement on the continental shelf. This peculiar seismic unit is characterized by seaward dipping reflectors. The basal contact of this unit is erosive and toplaps are observed upward, suggesting that its deposition occurred between two phases of emersion. As this seaward dipping unit correlates with Pliocene deposits near the shoreline, we propose that it corresponds to foresets of the Pliocene Gilbert delta (Figure 11).

\subsection{Lateral Variations of the Pre-MSC Unit}

[34] Changes in thickness of sedimentary deposits may be related to several factors, including the presence of reliefs at the time of deposition (paleotopography [e.g., Maillard et al., 2003]). We focus on thickness changes of pre-MSC unit together with changes in the depth of its base in order to recognize topography prior to the MSC. We focus on 2 peculiar zones: the deep basin east of the Algiers ridge (Figures 6 and 8) and west of Algiers (Figure 12). In these two areas, the small amount of salt allows to observe preMSC units.

[35] East of the Algiers ridge, we observe the typical preMSC unit as described above. Deposits exhibit thickness and depth to basement variations. Where the basal contact is visible, pre-MSC deposits are onlapping the acoustic basement (Figures 6 and 8). This onlap occurs where the acoustic basement forms topographic highs. Elsewhere, seismic reflectors can be observed down to $\sim 1 \mathrm{~s}$ TWTT below the base of the MSC deposits without reaching the basement. We mapped the position of basement highs using the whole MARADJA data set: three basement highs are highlighted (Figure 3). They have an elongated shape trending $\mathrm{N} 70^{\circ}$, and their size is more that $10 \mathrm{~km}$ long and about $3 \mathrm{~km}$ wide (Figure 3). The basement highs are separated from each other by a 10 to $20 \mathrm{~km}$ wide basin that has been filled during early to middle Miocene times (Figures 5 and 6).

[36] West of Algiers, we do not recognize the pre-MSC unit as defined east and north of Algiers: amplitude and frequency of the reflections rapidly decrease (Figure 12) and no reflections are observed below $5.25 \mathrm{~s}$ TWTT, which suggests that the MSC unit overlies a strongly reduced preMSC unit and/or directly the basement and that basement of the deep basin was in a higher position west of Algiers than east of Algiers. Toward the north, no basement highs are inferred from our observations and from published basement maps [Mauffret, 2007].

[37] Between these two areas (west and east of Algiers ridge), large amounts of salt form abundant salt domes. When these domes occur, the pre-MSC unit is not well observed. Few observations are possible between the salt domes. For instance, a pre-MSC unit similar to the preMSC unit east of the Algiers ridge has been observed. On the published basement map from Mauffret [2007], a basement high is also documented below the Algiers ridge, which suggests that the basement of this area has a similar structural pattern, i.e., that several basement highs formed during Miocene time and were filled by Miocene subbasins.

[38] These observations suggest that in the deep basin, the base of the pre-MSC unit is strongly irregular prior to the deposition of the pre-MSC unit. Following Cope [2003], we propose that the basement highs located east of Algiers represent the head of tilted blocks formed during the early stages of the Algerian basin formation (i.e., rifting). Such hypothesis is supported by the following three arguments: (1) basement highs are located where heads of tilted blocks are supposed to be found, i.e., over the deep Algerian margin and at the ocean-continent transition; (2) the peculiar orientation, spacing (about 15-20 km), and distribution of the basement highs is similar to the tilted block structural pattern observed typically in passive margins (e.g., the Iberia abyssal plain [Krawczyk et al., 1996] or the Ligurian margin [Rollet et al., 2002]); (3) the basement highs exist before the MSC, since the pre-MSC unit onlaps them. This hypothesis is consistent with a Late Oligocene or early Miocene age of rifting hypothesized between Iberia and Kabylies [Schettino and Turco, 2006, and references therein]. West of Algiers, the occurrence of one large basement high 

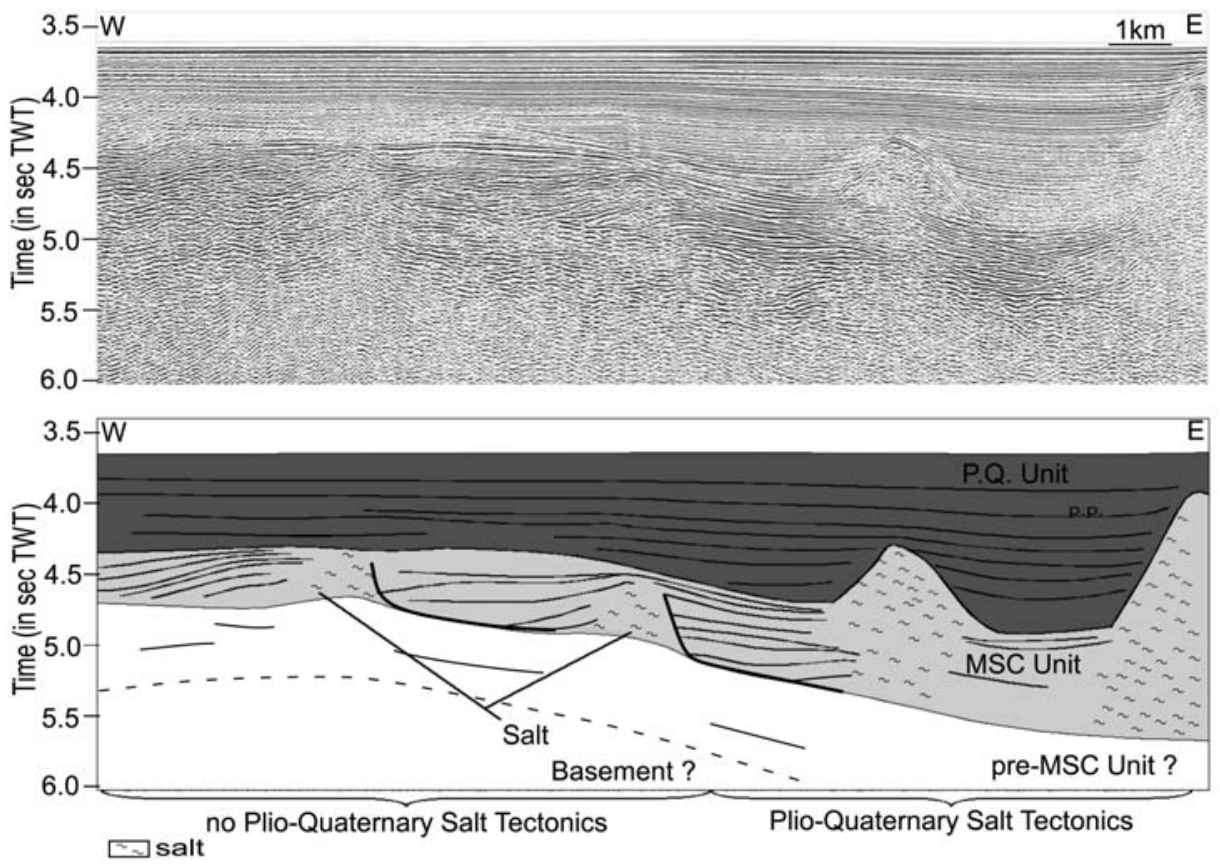

Figure 12. Line drawing of a representative six-channel seismic profile parallel to the Algerian margin, crossing the seaward continuation of the Thenia fault offshore (location in Figure 3). Vertical exaggeration is $3 \times$ at the seafloor.

in the deep basin suggests that the tilted block size is changing or that extension is taken up elsewhere.

\subsection{Early Pliocene Morphology of the Margin}

[39] We focus here on thickness changes of MSC unit together with changes of the depth of its base in order to recognize topography prior to Pliocene time and the location of Pliocene and Pleistocene vertical displacements. We focus on 3 peculiar zones: the deep basin east and north of Algiers, the deep basin west of Algiers, and the KADB.

[40] East of Algiers, at many locations on the seismic lines, we observe the occurrence of a MSC chaotic body near the foot of the continental slope (Figure 6) [Déverchère et al., 2005]. In other places of the western Mediterranean basin, a chaotic unit has been identified in a similar position relative to the continental slope [Sage et al., 2005, Lofi et al., 2005]. This observation suggests that the foot of the continental slope of the Algerian margin has not been strongly uplifted and deformed since the MSC. In the deep basin, we recognize the following succession: basement, pre-MSC unit, MSC unit and Plio-Quaternary (Figures 6 and 8). The depth of base of the Plio-Quaternary and MSC units range between 3.5 and 5.0 s TWTT and 4.4 and $5.5 \mathrm{~s}$ TWTT, respectively (Figure 13). Thicknes of the PlioQuaternary and MSC units ranges between and 0.0-1.4 and 0.2-1.4 s TWTT, respectively (Figure 13). For each unit, we observe lateral changes of depths and thicknesses: depth and thickness variability increases toward the west. The increase in thickness variability is related to a large abundance of salt in the MSC unit forming salt domes that in some places reach the seafloor. The large abundance of salt can be explained by (1) a Messinian paleobathymetric low, leading to accumulation of salt and then thickening of the MSC unit and/or (2) a Plio-Quaternary relative subsidence leading to salt migration and accumulation north of Algiers. We propend toward the second hypothesis because of evidence of salt migration at the boundary from east to west (Figure 9), and the constant thickness of the pre-MSC unit. Salt diapirism is also still active today, as examplified by salt walls outcropping on the seafloor [Déverchère et al., 2005; Dan et $a l ., 2010]$. Thus, we propose that the depth and thickness changes within the area east of Algiers are related to a relative uplift of the deep basin during the Plio-Quaternary.

[41] West of Algiers, the KADB consists of a large continental shelf, separated from the deep basin by an E-Wstriking steep continental slope (Figure 5). A borehole has been drilled during the $70 \mathrm{~s}$ at $10 \mathrm{~km}$ from the shoreline [Burollet et al., 1978]. A $50 \mathrm{~m}$ thick PQ unit directly covers lower Messinian, to Langhian continuous series. Thicknesses are $150 \mathrm{~m}, 300 \mathrm{~m}$ and $400 \mathrm{~m}$ for the lower Messinian, the Tortonian and the Serravalian, respectively [Burollet et al., 1978] (Figure 11). Microfauna associations indicate an outer shelf deposition environment for the Miocene deposits [Burollet et al., 1978]. Seismic lines on the bank across strike show that the depth of the erosion surface between the PlioQuaternary and the pre-MSC units is progressively increasing toward the North (Figure 11), and that the thickness of the Plio-Quaternary unit increases up to $0.8 \mathrm{~s}$ TWTT. Where the MSC erosion surface reaches a depth of $2 \mathrm{~s}$ TWTT, the chaotic MSC unit appears downslope between pre-MSC and Plio-Quaternary units. These observations are strong arguments for the emersion of a part of the KADB during the MSC 

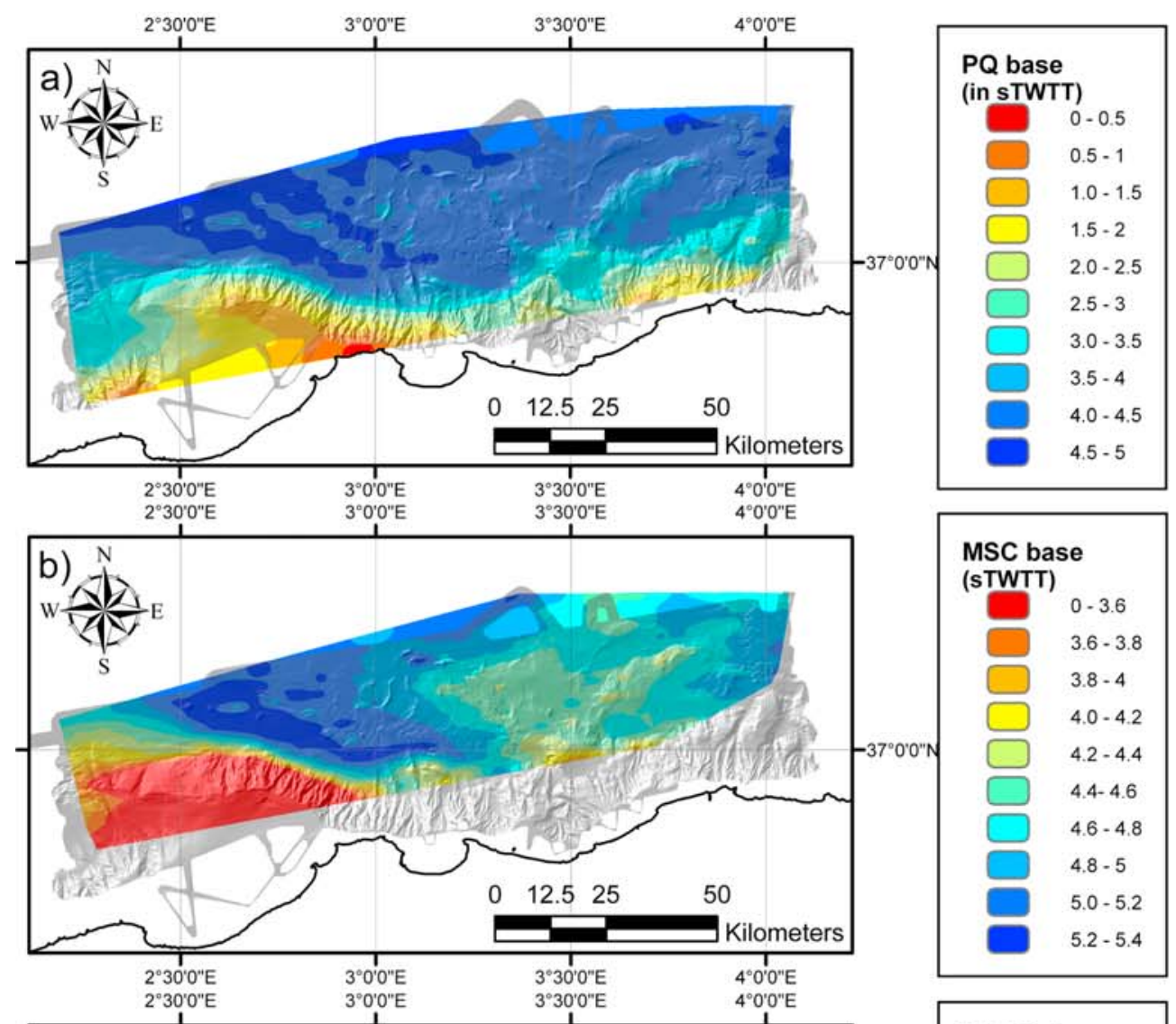

\section{MSC base} (sTWTT)
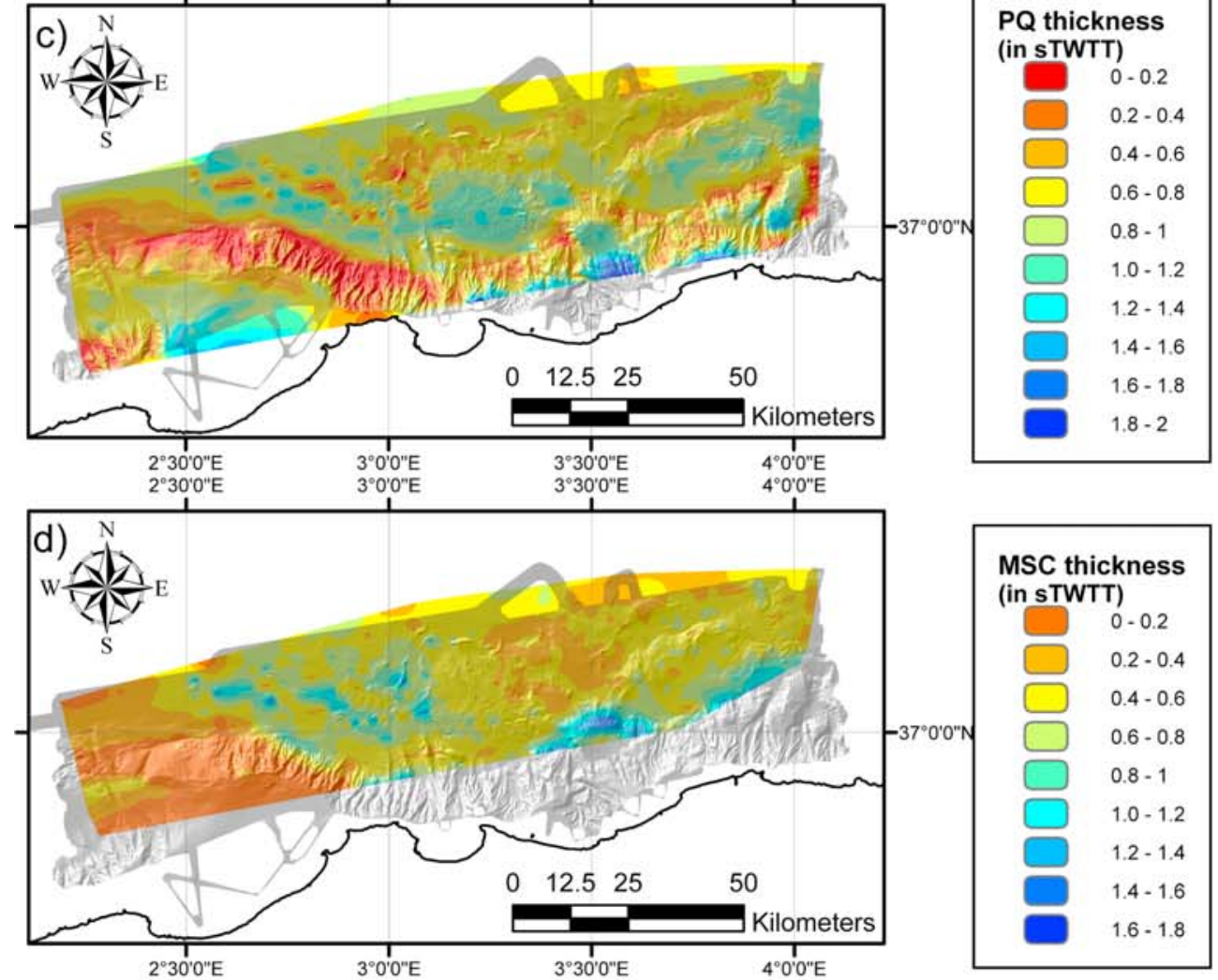

Figure 13. Depth and thickness of the PQ and MSC units in the Algiers area. Grid has been calculated using the whole MARADJA seismic survey and interpolated using the Kingdom Suite software. 
(Figures 10 and 11) [Domzig et al., 2006; Yelles et al., 2009]. At its maximum depth, the erosion surface is at about $1500 \mathrm{~m}$ under present-day sea level (Figure 10), in good agreement with the $\sim 1500 \mathrm{~m}$ of sea level fall proposed for the MSC event [e.g., Clauzon, 1996]. This suggests that the middle part of the KADB does not record uplift or subsidence greater than 200 or $300 \mathrm{~m}$ (Figure 10). In addition, the outer shelf deposition environment for the Miocene deposits suggests that the KADB is a topographic high at least since middle Miocene time. Based on these arguments, we propose that the KADB represents the offshore continuation of Kabylian continental units as expressed onshore by the Cherchell and Algiers massifs (Figure 3) [Domzig et al., 2006, Yelles et al., 2009].

[42] In the deep basin, the depth of the base of the PlioQuaternary and MSC units ranges between 3.5 and $4.5 \mathrm{~s}$ TWTT and 4.0-4.8 s TWTT, respectively. Thicknesses range between 0.2 and $0.6 \mathrm{~s}$ TWTT and $0.2-0.4 \mathrm{~s}$ TWTT. Depths and thicknesses increase from the continental slope to the north. The MSC unit is characterized by poor abundance of salt (Figure 12). The absence of the pre-MSC unit together with the reduced thickness of the Plio-Quaternary and MSC unit argues in favor of a relatively higher position of the basement in the deep basin and north of the KADB than further east. Such high position of the basement is documented since at least the Miocene period.

[43] The transition between the KADB and the deep basin North of the KADB consists of a 2000 m high topographic scarp following a W-E trend (Figure 10). Lateral changes in the MSC unit and in the pre-MSC formations [Burollet et al., 1978] suggest that this scarp has existed since Miocene time. We propose that such a scarp represents a normal fault surface active during the opening of the Algerian basin.

\subsection{Plio-Quaternary Tectonic Structures}

[44] Since the bathymetric and seismic acquisition of the MARADJA surveys in 2003 and 2005, compressive structures have been described in many locations of the Algerian margin [Déverchère et al., 2005; Domzig et al., 2006; Kherroubi et al., 2009; Yelles et al., 2009]. As in other parts of the Mediterranean basins, Plio-Quaternary deposits are strongly affected by salt tectonics (see Figures 5, 6, and 9 for instance). In the Algerian basin, salt tectonics complicates the recognition of structures related to the shortening of the margin as in most cases it does not only predate but is also synchronous with regional shortening (Figures 6 and 7). To avoid the problem of salt tectonics, previous authors focused on offsets of the MSC unit base. Unfortunately, this method is not suitable to determine precisely the onset of tectonics, as the considered reflections predate this onset. Below, we focus on the recognition of the reflections contemporaneous with salt tectonics and with regional shortening in order to estimate the relative timing of the deformation across the Algerian margin and the amount of shortening (Figure 7).

[45] East and north of Algiers, tectonics has been described on the continental slope and in the deep basin [Déverchère et al., 2005]. On the continental shelf, there are no fault-scale deformations affecting the most recent layers [Déverchère et al., 2010]. These deposits are about $30 \mathrm{~m}$ thick, and late Quaternary age has been proposed on the basis of microfauna associations. Below this unit, we recognize seaward dipping reflections compatible with foresets of Pliocene Gilbert deltas. The dip of the horizon is constant, suggesting that no deformation affects the Pliocene deposits. On the continental slope and in the deep basin, we recognize most of the Plio-Quaternary tectonic structures. Above most of the perched basins DPB1 and DPB2 (Figure 5), structures are poorly imaged because of the steep bathymetric slope, and compressive structures are difficult to highlight (Figures 5, 6, and 9). On several seismic profiles, we observe the folding of MSC chaotic unit over DPB 1 (Figure 6) [Déverchère et al., 2005]. At the foot of the continental slope and in the deep basin, in agreement with Déverchère et al. [2005] and Domzig et al. [2006], we recognize at least 6 anticlines on the MARADJA seismic survey (Figure 3). In order to constrain orientation and extent of each anticline, we use simultaneously seismic sections and isochron maps of the MSC unit base. East of the Algiers ridge (Figure 5), anticline lengths range between 16 and $42 \mathrm{~km}$, and their trend is relatively constant between $\mathrm{N} 60^{\circ}$ and $\mathrm{N} 70^{\circ}$ (see Anticlines 1, 2, 3, 4, on Figure 3). North of the Algiers ridge, anticlines 5 and 6 are 20 and $40 \mathrm{~km}$ long and trend $\mathrm{N} 80^{\circ}$ to $\mathrm{N} 100^{\circ}$ (Figure 3 ). For all these structures, the asymmetry of the folds suggests that deformation is related to south-dipping reverse faulting at depth [Déverchère et al., 2005].

[46] We recognize reflections associated with the onset of tectonics on Anticlines 1, 2, 3, 5, 6. For all these folds, we observe that deformation started during the Plio-Quaternary (Figures 6 and 8). In absence of better time constraints within the Plio-Quaternary units, no more precise time inferences are proposed.

[47] West of Algiers (Figure 10), recent deformation has been recognized on the continental shelf (i.e., KADB) and in the deep basin [Domzig et al., 2006]. On the top of the $\mathrm{KADB}$, the Plio-Quaternary unit covers the foresets of the Pliocene Gilbert delta, and Miocene deposits are locally evidenced (Algiers borehole [Burollet et al., 1978]). Because foresets of the Pliocene Gilbert delta are present on some seismic sections (Figure 11) and absent on other ones (Figure 10), we propose that these deposits are discontinuous and are filling Messinian canyons. The Miocene unit forms an anticline near the edge of the continental shelf (Anticline 7 on Figure 11): on its northern flank, growth strata argue in favor of a tectonic activity prior to the MSC, whereas PlioQuaternary deposits are folded along the southern flank, suggesting that anticline growth has continued during PlioQuaternary times. Another fold, $20 \mathrm{~km}$ long and striking $\mathrm{N} 45^{\circ}$, is located at the top of the continental shelf further west (Anticline 8 on Figure 10): since growth strata developed within the upper unit, this structure is of Plio-Quaternary age (Figure 10) [Domzig et al., 2006; Yelles et al., 2009]. Asymmetry of the fold on the continental shelf argues for a north-dipping blind thrust. A third Pliocene-Pleistocene fold follows the foot of the KADB: this is a $80 \mathrm{~km}$ long asymmetric fold oriented $\mathrm{N} 70^{\circ}-\mathrm{N} 90^{\circ}$ (Anticline 9 on Figure 10), consistent with a blind south-dipping thrust at depth [Domzig et al., 2006; Yelles et al., 2009]. No additional compressive structures are observed further north in the deep basin, neither 
in our data set nor on other published data sets [Mauffret, 2007]. The onset of tectonic folding at Anticlines 8 and 9 takes place during the Pliocene-Pleistocene period, after the deposition of an isopach layer at the base of the PliocenePleistocene period (Figure 7). The relative timing of the deformation in the KADB and at the foot of the slope is unfortunately impossible to estimate, because of the lack of depositional continuity on the steep continental slope (Figure 10).

\section{Discussion}

\subsection{Relationships Between Recent and Preexisting Tectonic Structures}

[48] Along the foot of the Algerian margin and in the deep basin, the distribution of the Pliocene-Pleistocene deformations appears generally closely related to pre-MSC structures: continental slope and basement discontinuities of the so-called transitional crust seem to focus the deformation and to be responsible for changes in the tectonic style. Two main locations of tectonic structures are evidenced:

[49] 1. The first is the foot of the continental slope. Anticlines 1, 5 and 9 are located at the Algerian basin boundary (Figure 3 ). This fact suggests that the basin limits, directly inherited from the basin formation during lower Miocene time, play an important role on strain focusing.

[50] 2. The second is the deep basin. In the part of the Algerian basin located east of Algiers, we recognize three basement highs which are proved to exist prior to recent folding. There is clearly a good concordance in the position of deep basement highs and Pliocene-Pleistocene structures (Figures 3, 6, and 8). Below Anticline 5, the lack of penetration of our seismic lines prevents us from any observation of the basement highs (Figures 3 and 9). However, basement highs are also documented below Anticline 6 on published basement map of the Algerian basin [Mauffret, 2007].

[51] West of Algiers, the large-scale basement high located in the deep basin is associated with a deformation pattern different from the one found east of Algiers (Anticline 9 in Figure 3): only one fold takes place at the foot of the continental slope. Here, the thick and large basement high seems to prevent deformation within the deep basin.

[52] The association between the location of basement highs and Pliocene-Pleistocene tectonic structures in the deep Algerian basin suggests that the Algerian rifted margin underwent a tectonic inversion within a roughly $\mathrm{N}-\mathrm{S}$ compressional regime. The basements highs of the deep Algerian margin extend within the ocean-continent transitional crust [Roca et al., 2004]. The pattern of alternating basin highs and lows is commonly found elsewhere along continental margins depicting stretched continental crusts, as for instance off Galicia [e.g., Krawczyk et al., 1996; Peron-Pinvidic et al., 2008, and references therein], which are born before continental breakup. On the Algerian margin, basement highs originated $25 \mathrm{Ma} \mathrm{BP}$ in an extensional regime, as testified by the presence of tilted blocks and large normal faults, and were later reactivated within the Plio-Quaternary compressional stress field.

[53] Blind thrust faults located at the foot of the Algerian continental slope and in the deep basin dip toward the south: this dip is supported by the asymmetry of PliocenePleistocene folds and also by the dip of the rupture plane of the 2003 Boumerdès earthquake [Delouis et al., 2004]. As early Miocene normal faults dip toward the deep basin, preexisting normal faults themselves are not inverted. Since "new," south-dipping blind thrust faults take place at the foot of basement highs, we infer that their position is controlled either by more favorably oriented structures inherited from rifting [Krawczyk et al., 1996] or by lateral changes in body forces which occur at the contact between the basement highs and lows. Because the nature of the basement is unknown, we have no way to check whether deformation is localized in a zone of possible exhumed continental mantle, as found in the west Iberia margin [Peron-Pinvidic et al., 2008], which is supposed to represent the weakest part in magma-poor margins. However, our case is different in the sense that deformation structures obviously correlate with basement domains of the lower, middle, and upper parts of the margin: this observation suggests that exhumed continental mantle may not exist off Algeria.

\subsection{Origin and Significance of the Transition Between East and West of Algiers}

[54] The present study highlights sharp differences between two adjacent parts of the Algerian margin. Offshore, these differences are as follows: (1) the size of the continental shelf, which is strongly reduced east of Algiers whereas it is wide west of Algiers (Figures 3 and 5); (2) the position of the PlioQuaternary compressive structures in the deep basin: the deformation is widely extending in the deep basin east of Algiers whereas it is limited to a unique fold west of Algiers (Figures 3, 6, and 10); (3) the thickness of the pre-MSC, MSC and Plio-Quaternary units: they are thinner west of KADB, suggesting that the seafloor was higher since at least the deposition of the pre-MSC unit (Figures 6, 8, 12, and 13); and (4) the Oligo-Miocene structure of the margin: it has been demonstrated that the Plio-Quaternary deformation pattern is controlled by structures inherited from the basin opening. Thus, changes of the deformation pattern are reflecting changes of the Oligo-Miocene structure of the margin (Figure 3). Onshore, differences are observed regarding (1) the present-day morphology: reliefs are located east of Algiers with more than $2000 \mathrm{~m}$ high mountains whereas small reliefs are observed west of Algiers (Figure 3), and (2) the uplift history: sedimentary series record evidence for a $1000 \mathrm{~m}$ uplift during the Tortonian, whereas no uplift is recorded during the same period west of Algiers (Figure 4).

[55] The boundary between these two domains is oriented $\mathrm{N} 120^{\circ}$ and follows from SE to NW the western boundary of the Grande Kabylies, crosses the shore at Cape Matifou and underlines the eastern boundary of the KADB (Figure 3). In the deep basin, this boundary has no morphologic expression but a similar $\mathrm{N} 120^{\circ}$ trend is observed on the map of the Plio-Quaternary and MSC units (Figure 13). On both sides of the boundary, we observe an offset of several tens of kilometers (1) of the northern boundary of the Kabylian blocks: it follows the shoreline east of Algiers and is located $45 \mathrm{~km}$ north of the shoreline west of Algiers (Figure 3), and 
(2) of the southern boundary of the Kabylian blocks: the Djurdjura units is located $50 \mathrm{~km}$ south of the shore line east of Algiers and at less that $10 \mathrm{~km}$ from the shore line in the Chenoua massif (Figure 2). These observations strongly suggest that this $\mathrm{N} 120^{\circ}$ boundary represents a previous strike-slip fault zone responsible for several tens of kilometers dextral offset. The timing of fault motion is constrained by the youngest age of Djurdjura massif deposits that are affected by dextral offsets and the age of the oldest deposits that are not affected by dextral offset [Saadallah et al., 1996]. This limits the time lapse for dextral offset between Eocene and the Burdigalian times, i.e., during the time lapse ranging from Tethysian subduction and Algerian basin opening to the Kabylian collision [Rosenbaum and Lister, 2004; Schettino and Turco, 2006].

[56] On the basis of the map of magnetic anomalies of the Algerian basin, it has been proposed that several $\mathrm{N} 120^{\circ}$ dextral strike-slip faults were associated with the opening of the Algerian basin and the drifting of the Kabylian block to the south [Schettino and Turco, 2006] (Figure 2). We propose that these oceanic discontinuities can be followed from the deep Algerian basin through the Algerian margin and onshore up to the western limit of the Grande Kabylies block (Figure 3). The dextral motion of this fault then occurred during the opening of the Algerian basin and probably stopped at the time of collision, i.e., 19 Ma ago.

\subsection{Present-Day Importance and Activity of the N120 Boundary}

[57] Whether or not the $\mathrm{N} 120^{\circ}$ boundary between the KADB and the offshore domain off Boumerdès-Algiers is still active today is debated [Mauffret et al., 1987; Mauffret, 2007; Déverchère et al., 2005; Yelles et al., 2009]. From subsurface morphology on the eastern flank of the KADB, Yelles et al. [2009] have proposed that this transition represents today a wide relay zone which progressively accommodates the relative movements between the BoumerdesZemmouri fault zone and the Khayr al Din main fault. In this study, we show that the N120 $0^{\circ}$ structural boundary (Figures 3 and 4) underlines a major change in the Plio-Quaternary tectonic style along the Algerian margin. Here, we discuss further evidence on the role of this boundary. First, coseismic and postseismic deformations associated with the 2003 Boumerdès earthquake suggests a control by this inherited structure: indeed, it has been observed that the coseismic rupture and coseismic shoreline uplift related to this event are limited to the eastern side of the Thenia fault [Ayadi et al., 2008]. Furthermore, a strong decrease of the shoreline uplift occurred across the $\mathrm{N} 120^{\circ}$ boundary, as $0.70 \pm 0.15 \mathrm{~m}$ of costal uplift was observed in the city of Boumerdès and no costal uplift occurred $3 \mathrm{~km}$ further west. Second, when looking at the aftershock sequence, the following changes are observed related to the $\mathrm{N} 120^{\circ}$ boundary: (1) east of the $\mathrm{N} 120^{\circ}$ boundary, aftershocks are located around the shore line or at sea and correspond to thrusting events along a south-dipping fault [Braunmiller and Bernardi, 2005; Ayadi et al., 2008]; (2) west of the $\mathrm{N} 120^{\circ}$ boundary, aftershocks correspond to thrusting events along a nearly vertical fault zone between 4 and $14 \mathrm{~km}$ depth, and most epicenters are located onshore and follow the southern boundary of the Mitidja valley; and (3) on the $\mathrm{N} 120^{\circ}$ boundary itself, aftershocks are mostly left lateral strike-slip events [Braunmiller and Bernardi, 2005; Ayadi et al., 2008].

[58] Because lateral changes of coseismic and postseismic deformations coincide with the position of the inherited $\mathrm{N} 120^{\circ}$ boundary, we propose that this preexisting structure inherited from the opening of the Algerian basin plays a key role on the distribution of seismic and postseismic deformation: indeed, left lateral strike-slip events along the N120 boundary are accommodating the differential (northwestward) motion of the eastern blocks relative to the western blocks, in a sense opposite to the motion of this structure during the opening of the Algerian basin (see section 6.2). Whether or not this limit may rupture along all its length during a single event, thus increasing the level of seismic hazards, remains unclear and requires further investigations.

\subsection{Implication for Tectonics at the Africa-Europe Boundary and Subduction Inception}

[59] The first argument in favor of subduction inception along the Algerian margin was the discovery of a downwarping of recent sedimentary layers at the foot of the central and eastern Algerian margin [Auzende et al., 1972]. However, no direct evidence for reverse faulting at the seafloor has been found [Mauffret et al., 1992; Domzig et al., 2006]. Déverchère et al. [2005] report for the first time blind reverse structures along the central Algerian margin and propose that these reverse faulting marks the onset of underthrusting of the Neogene oceanic crust. There are at least the following three arguments for a subduction inception north of central Algeria:

[60] 1. Downwarping of the pre-Pliocene sediments in a $\sim 50 \mathrm{~km}$ wide strip along the foot of the Algerian margin [Auzende et al., 1972] associated to a systematic negative gravity anomaly [Auzende et al., 1975] are important singularities of this margin in the western Mediterranean sea. Actually, following Auzende et al. [1972], we verify that there is no evidence for the formation of a bathymetric trench at this place, suggesting that the formation of uplifted basins and continuous deposition of sediments counterbalance this local subsidence.

[61] 2. Reverse structures are dominantly located at the foot of the continental slope and are dipping to the south [Déverchère et al., 2005; Domzig et al., 2006; Kherroubi et al., 2009; Yelles et al., 2009], in agreement with results of analog experiments on subduction inception [Faccenna et al., 1999; Mart et al., 2005].

[62] 3. Uplift of the continent is observed along the coastal domain [De Lamothe, 1911; Meghraoui, 1991; Boudiaf, 1996], in good agreement with continental uplift observed in similar contexts (e.g., New Zealand [House et al., 2002]) or in numerical modeling during initiation of subduction [Gurnis et al., 2004].

[63] However, the geometry of the southward-dipping fold and thrust system identified at the foot of the central and eastern Algerian margin [Déverchère et al., 2005; Domzig et al., 2006; Kherroubi et al., 2009; Yelles-Chaouche et al., 2009; Yelles et al., 2009] invalidates a model of an almost 
continuous active fault system running from the Gibraltar strait up to the Sardinia Channel, as proposed by Mauffret [2007]. Instead, we evidence a series of discontinuous reverse segments separated by transcurrent zones whose activity in the present-day stress field is questionable, suggesting that the process of subduction is still in an immature stage. This result is important because it allows to propose an upper bound to the maximum earthquake size expected to occur on this fault system: if we hypothesize that the shifts between major fault segments are large enough (more than $4 \mathrm{~km}$ ) to prevent the rupture from propagating through these steps [Elliott et al., 2009, and references therein], a maximum magnitude of $M_{w} \sim 7.3$ is proposed for the largest fault of this system, namely the $\sim 80 \mathrm{~km}$ long Khayr Al Din fault (Anticline 9, Figure 3) [Yelles et al., 2009]. This result is in good agreement with the historical seismicity of northern Algeria [Rothé, 1950]. It is also worth noting that compressive deformation is found to propagate significantly in the deep basin only in the studied area east of Algiers (Boumerdès area [Déverchère et al., 2005], Figure 13), forming at least three successive flat and blind thrust ramps: this observation suggests that the subduction inception process is more advanced in this area than in the area west of Algiers.

[64] In the Alboran sea, the oceanic domain of the Algerian basin turns to a stretched continental lithosphere [Booth-Rea et al., 2007, and reference therein]: here, the Plio-Quaternary and active tectonics is dominated by strike-slip faulting [Mauffret et al., 1992; Stich et al., 2006; Fernandez-Ibañez et al., 2007, and references therin]. West of our studied area, between Oran and Tenes, there is no clear and undoubtful evidence for the development of compressive structures and of subsequent subduction inception at the foot of the Algerian margin [Domzig et al., 2006]. Thus, there is no continuity of the offshore compressive deformation between the subduction inception zone located north of Algeria and the Alboran Sea. Relying on the regional seismicity [Stich et al., 2006; Serpelloni et al., 2007], we propose that the convergence between the European and African plates in this area is mostly accommodated both in the Betic belt and in the Tell domain.

[65] North of Sicily, there is also evidence for shortening between the Aeolians Islands and Sicily [Serpelloni et al., 2005], suggesting the inception of a subduction below the north Sicilian margin [Billi et al., 2007]. Between approximatively $100 \mathrm{~km}$ east of the city of Annaba and western Sicily (Figure 1), African and European continental lithospheres are in contact: there, the northward motion of the African plate is probably accommodated by a dextral strike slip zone located in the strait of Sicily and in the TunisianPelagian Plateau, as evidenced by geologic structures [Jongsma et al., 1985, Catalano et al., 2008] and geodesy [Serpelloni et al., 2007]. In this context, the onset of subduction north of Sicily cannot be directly related to the onset of subduction north of Algeria, as there is no continuity of the oceanic lithosphere between Tyrrhenian and Algerian basins.

[66] We conclude that the oceanic domain of the Algerian basin could start to be subducted below the African plate between $1^{\circ} \mathrm{E}$ and $8.5^{\circ} \mathrm{E}$, i.e., along a $\sim 650 \mathrm{~km}$ long portion of the Algerian margin (Figure 1). We also emphasize that the onset of the contractional deformation located at the foot of the continental margin remains poorly constrained: it appears generally to have occurred during the PlioQuaternary time period; however, some structures may have started to develop prior to the Messinian Salinity Crisis. Whatever the timing of subduction inception, this process is active today at rates lower than $2 \mathrm{~mm} \mathrm{y}^{-1}$ [Serpelloni et al., 2007]. Recently, Kherroubi et al. [2009] have proposed an increase of the tectonic activity from west to east along the Algerian margin from a comparison between the Algiers and Annaba regions, the latter being assumed to undergo a more recent tectonic deformation (since about $1 \mathrm{Ma}$ ) and at a faster rate (about 3 times) than near Algiers, which suggests some diachroneity of this process. Note that the onset of the south-dipping thrust system at the northern limit of the Maghrebian orogenic wedge off northern Sicily is assumed to be even younger (500-700 kyrs [Goes et al., 2004]), suggesting different evolutionary stages of the Algerian and South Tyrrhenian margins. However, these differences from one area to another are only locally recognized and remain hardly possible to quantify. It is therefore difficult to compare accurately the timing of shortening in the entire northern margin of Africa.

\section{Conclusion}

[67] The Algerian rifted margin formed during early Miocene time in a context of back arc extension. The Algerian basin opening occurred until $\sim 15 \mathrm{Ma}$ and predates the onset of compression related to the closure of the Tethyan ocean and the growth of the Maghrebian orogen. The continuous Europe-Africa convergence is responsible for a progressive migration of the plate limit from the late Miocene, north-dipping suture zone on land, to a Plio-Quaternary, south-dipping fault system located at the foot of the margin in central and eastern Algeria, suggesting the initiation of subduction of the Neogene oceanic lithosphere. In the Algiers area, inversion of the Algerian margin is marked by the folding of the Pliocene-Pleistocene sequences, leading to the formation of young reliefs and the birth and growth of active fault-related folds both onshore (Algiers and Sahel-Tipaza areas, limit Atlas-Tell) and offshore. The deformation pattern is strongly controlled by preexisting structures such as the continent-ocean main boundary and basement highs within the deep basin. During margin inversion, Miocene normal faults were not reactivated in compression; instead, newly formed, south-dipping blind thrusts appeared (1) within the continental margin, (2) at the foot of the continental slope, and (3) at the northern ends of basement highs interpreted as stretched continental blocks of the rifted margin.

[68] We describe also strong lateral changes in the style of contractional tectonics along the margin: blind thrusts are located both onshore and offshore and are dipping to the southeast of Algiers whereas conjugated blind thrusts are dipping both to the north and to the southwest of Algiers. Change of the tectonic style is controlled by the presence of a transform fault inherited from the Algerian basin spreading and oriented $\mathrm{N} 120^{\circ}$. Such an inherited structure plays also 
an important role on the distribution of seismic and postseismic deformation and also determines a major discontinuity in the trace of the fault system which ultimately controls the earthquake size, assumed to reach magnitudes of 7.3. A similar structural control is apparent in the geometry of the fault system along northern Algeria, both offshore [Domzig et al., 2006; Yelles-Chaouche et al., 2009; Kherroubi et al., 2009] and onshore [Bouillin, 1992]. The Algerian margin appears to undergo a process of subduction inception only in its central and eastern parts. This process is likely to occur in similar way and position in the southern Tyrrhenian Sea.

[69] Acknowledgments. We thank the captain and crew of the IFREMER vessel "Le Suroit" and all the participants of the cruises MARADJA 2003 and 2005. This work was funded by the National (French) Agency for Research (ANR) projects ISIS (coordinator N. Sultan, IFREMER) and DANACOR (coordinator J. Déverchère, UBO). Additional funding (Second Year Post-Doctoral grant for P. Strzerzynski) was provided by CG29 (Conseil Général du Finistère). Many thanks to A. Billi and Y. Mart for constructive comments on this work.

\section{References}

Aïté, R., and J.-P. Gélard (1997), Post-collisional paleostresses in the central Maghrebides (Great Kabylia, Algeria), Bull. Soc. Geol. Fr., 168, 423-436.

Alvarez-Marron, J., E. Rubio, and M. Torne (1997), Subduction-related structures in the North Iberian margin, J. Geophys. Res., 102, 22,497-22,511, doi:10.1029/97JB01425

Auzende, J.-M., J. L. Olivet, and J. Bonnin (1972), Une structure compressive au nord de l'Algérie?, Deep Sea Res., 19, 149-155.

Auzende, J.-M., J. Bonnin, and J. L. Olivet (1975), La marge nord-africaine considérée comme marge active, Bull. Soc. Geol. Fr., 17, 486-495.

Ayadi, A., S. Maouche, A. Harbi, and M. Meghraoui (2003), Strong Algerian earthquake strikes near capital city, Eos Trans. $A G U, 84(50), 561-568$, doi:10.1029/2003EO500002.

Ayadi, A., C. Dorbath, F. Ousadou, S. Maouche, M. Chikh, M.A. Bounif, and M. Meghraoui (2008), Zemmouri earthquake rupture zone $\left(M_{w} 6.8\right.$, Algeria): Aftershocks sequence relocation and $3 \mathrm{D}$ velocity model, J. Geophys. Res., 113, B09301, doi:10.1029/2007JB005257.

Belanteur, O., H. Bellon, R. C. Maury, A. Ouabadi, A. Coutelle, B. Semroud, M. Megartsi, and S. Fourcade (1995), Miocene magmatism in eastern Algiers region; geology, geochemistry and $40 \mathrm{~K} / 40$ Ar geochronology, C. R. Acad. Sci. Ser. II, 321, 489-496.

Bellon, H., C. Lepvrier, J. Magne, and D. Raymond (1977), The eruptive activity in Algeria; new geochronologic data, Geol. Mediterr., 4, 291-298.

Billi, A., D. Presti, C. Faccenna, G. Neri, and B. Orecchio (2007), Seismotectonics of the Nubia plate compressive margin in the south Tyrrhenian region, Italy: Clues for subduction inception, J. Geophys. Res., 112, B08302, doi:10.1029/2006JB004837.

Bonneton, J.-R. (1977), Géologie de la zone de contact entre Mitidja et Atlas de Blida au Sud d'Alger, Ph.D. thesis, 115 pp., Univ. de Paris 6, Paris.

Booth-Rea, G., C. R. Ranero, J. M. Martinez-Martinez, and I. Grevemeyer (2007), Crustal types and Tertiary tectonic evolution of the Alboran sea, western Mediterranean, Geochem. Geophys. Geosyst., 8, Q10005, doi:10.1029/2007GC001639.

Boudiaf, A. (1996), Etude sismotectonique de la région d'Alger et de la Kabylie (Algérie): Utilisation des modèles numériques de terrain (MNT) et de la télédétection pour la reconnaissance des structures tectoniques actives: Contribution à l'évaluation de l'aléa sismique, Ph.D. thesis, 274 pp., Univ. de Montpellier II, Montpellier, France.

Boudiaf, A., J.-F. Ritz, and H. Philip (1998), Drainage diversions as evidence of propagating active faults: Example of the El Asnam and Thenia faults, Algeria, Terra Nova, 10, 236-244, doi:10.1046/j.13653121.1998.00197.x.

Boudiaf, A., H. Philip, A. Coutelle, and J.-F. Ritz (1999), Découverte d'un chevauchement d'âge quaternaire au sud de la grande Kabylie (Algérie), Geodyn. Acta, 12(2), 71-80.

Bouillin, J.-P. (1986), Le bassin maghrébin: Une ancienne limite entre l'Europe et l'Afrique à l'Ouest des Alpes, Bull. Soc. Geol. Fr., 8(4), 547-558.
Bouillin, J.-P. (1992), La repartition des affleurements de la Dorsale kabyle: Héritage d'une segmentation mésozoïque de la marge nord-téthysienne?, $C . R$ Acad. Sci. Ser. II, 315, 1127-1132.

Bounif, A., M. Bezzeghoud, L. Dorbath, D. Legrand, A. Deschamps, L. Rivera, and H. Benhallou (2003), Seismic source study of the 1989 October 29 , Chenoua (Algeria) earthquake from aftershocks, broad-band and strong motion records, Ann. Geophys., 46, 625-646.

Bounif, A., et al. (2004), The 21 May 2003 Zemmouri (Algeria) earthquake $M_{w}$ 6.8: Relocation and aftershock sequence analysis, Geophys. Res. Lett., 31, L19606, doi:10.1029/2004GL020586.

Bracene, R., and D. Frizon de Lamotte (2002), The origin of intraplate deformation in the Atlas system of western and central Algeria: From Jurassic rifting to Cenozoic-Quaternary inversion, Tectonophysics, 357, 207-226, doi:10.1016/S0040-1951(02)00369-4.

Brandes, C., A. Astorga, P. Blisniuk, R. Littke, and J. Winsemann (2007), Anatomy of anticlines, piggyback basins and growth strata; a case study from the Limon fold and thrust belt, Costa Rica, in Sedimentary Processes, Environments and Basins: A Tribute to Peter Friend, Int. Assoc. Sedim. Spec. Pub. Ser. vol. 38, edited by G. Nichols, E. Williams, and C. Paola, pp. 91-110, Blackwell, Malden, Mass.

Braunmiller, J., and F. Bernardi (2005), The 2003 Boumerdes, Algeria earthquake: Regional moment tensor analysis, Geophys. Res. Lett., 32, L06305, doi:10.1029/2004GL022038.

Burollet, P. F., A. Said, and P. Trouve (1978), Slim holes drilled on the Algerian shelf, Initial Rep. Deep Sea Drill. Proj., 42(2), 1181-1184.

Calais, E., C. DeMets, and J.-M. Nocquet (2003), Evidence for a post-3.16-Ma change in Nubia-EurasiaNorth America plate motions?, Earth Planet. Sci. Lett., 216, 81-91, doi:10.1016/S0012-821X(03) 00482-5.

Carminati, E., M. J. R. Wortel, W. Spakman, and R. Sabadini (1998), The role of slab detachment process in the opening of the western-central Mediterranean basins: Some geological and geophysical evidence, Earth Planet. Sci. Lett., 160, 651-665, doi:10.1016/S0012-821X(98)00118-6.

Catalano, S., G. De Guidi, G. Romagnoli, S. Torrisi, G. Tortorici, and L. Tortorici (2008), The migration of plate boundaries in SE Sicily: Influence on the large-scale kinematic model of the African promontory in southern Italy, Tectonophysics, 449, 41-62, doi:10.1016/j.tecto.2007.12.003.

Clauzon, G. (1996), Limites de séquences et évolution géodynamique, Géomorphologie, 1, 3-22.

Cope, M. J. (2003), Algerian licensing round may offer opportunity for exploration plays in deep offshore frontier, First Break, 21, 37-42.

Coutelle, A. (1979), Géologie du sud-est de la grande Kabylie et des Babors d'Akbou, Ph.D. thesis, 191 pp., Univ. of Paris VI, Paris.

Dan, G., N. Sultan, B. Savoye, J. Déverchère, and K. Yelles (2009), Quantifying the role of sandy-silty sediments in generating slope failures during earthquakes: Example from the Algerian margin, Int.
J. Earth Sci., 98, 769-789, doi:10.1007/s00531008-0373-5

Dan, G., B. Savoye, V. Gaullier, A. Cattaneo, J. Déverchère, K. Yelles, and MARADJA 2003 team (2010), Algerian margin sedimentation patterns (Algiers area, southwestern Mediterranean), in Mass Transport Deposits in Deepwater Settings, edited by R. C. Shipp, P. Weimer, and H. W. Posamentier, Spec. Publ. SEPM Soc. Sediment. Geol. Ser., in press.

De Lamothe, R. (1911), Les anciennes lignes de rivage du Sahel d'Alger et d'une partie de la côte algérienne, Mem. Soc. Geol. Fr., 6, 1-288.

Delouis, B., M. Vallée, M. Meghraoui, E. Calais, S. Maouche, K. Lammali, A. Mahsas, P. Briole, F. Benhamouda, and K. Yelles (2004), Slip distribution of the 2003 Boumerdes-Zemmouri earthquake, Algeria, from teleseismic, GPS, and coastal uplift data, Geophys. Res. Lett., 31, L 18607 , doi:10.1029/2004GL020687.

Déverchère, J., et al. (2005), Active thrust faulting offshore Boumerdes, Algeria, and its relations to the $2003 M_{w} 6.9$ earthquake, Geophys. Res. Lett., 32 , L04311, doi:10.1029/2004GL021646.

Déverchère, J., B. Mercier de Lépinay, A. Cattaneo, P. Strzerzynski, E. Calais, A. Domzig, and R. Bracene (2010), Comment on "Zemmouri earthquake rupture zone ( $M_{w} 6.8$, Algeria): Aftershocks sequence relocation and 3D velocity model" by Ayadi et al., J. Geophys. Res., doi:10.1029 2008JB006190, in press

Dewey, J. F., M. Helman, S. D. Knott, E. Turco, and D. Hutton (1989), Kinematics of the western Mediterranean, Geol. Soc. London Spec. Publ., 45 265-283.

Domzig, A., et al. (2006), Searching for the AfricaEurasia Miocene boundary offshore western Algeria (MARADJA'03 cruise), C. R. Geosci., 338, 80-91, doi:10.1016/j.crte.2005.11.009.

Doré, A. G., E. R. Lundin, N. J. Kusznir, and C. Pascal (2008), Potential mechanisms for the genesis of Cenozoic domal structures on the NE Atlantic margin: Pros, cons and some new ideas, Geol. Soc. Spec. Publ., 306, 1-26, doi:10.1144/SP306.1.

Elliott, A. J., J. F. Dolan, and D. D. Oglesby (2009), Evidence from coseismic slip gradients for dynamic control on rupture propagation and arrest through stepovers, J. Geophys. Res., 114, B02313, doi:10.1029/2008JB005969.

Faccenna, C., D. Giardini, P. Davy, and A. Argentieri (1999), Initiation of subduction at Atlantic-type margins: Insights from laboratory experiments, $J$. Geophys. Res., 104, 2749-2766, doi:10.1029/ 1998JB900072.

Faccenna, C., C. Piromallo, A. Crespo-Blanc, L. Jolivet, and F. Rossetti (2004), Lateral slab deformation and the origin of the western Mediterranean arcs, Tectonics, 23, TC1012, doi:10.1029/2002TC001488.

Fernandez-Ibañez, F., J. I. Soto, M. D. Zoback, and J. Morales (2007), Present-day stress field in the Gibraltar Arc (western Mediterranean), J. Geophys. Res., 112, B08404, doi:10.1029/2006JB004683.

Fitzgerald, P. G., J. A. Muñoz, P. J. Coney, and S. L. Baldwin (1999), Asymmetric exhumation across 
the central Pyrenees: Implications for the tectonic evolution of a collisional orogen, Earth Planet. Sci. Lett., 173, 157-170, doi:10.1016/S0012-821X (99)00225-3

Gaullier, V., Y. Mart, G. Bellaiche, J. Mascle, B. Vendeville, and T. Zitter, and Second Leg Prismed II Scientific Party (2000), Salt tectonics in and around the Nile Deep-Sea Fan: Insights from 'PRISMED II' cruise, Geol. Soc. Spec. Publ., $174,111-129$

Gautier, F., G. Clauzon, J.-P. Suc, J. Cravatte, and D. Violanti (1994), Age et durée de la crise de salinité messinienne, C. R. Acad. Sci. Ser. II, 318, 1103-1109.

Glangeaud, L. (1952), Histoire géologique de la province d'Alger, C. R. Congr. Geol. Int., 25, 1-141.

Goes, S., D. Giardini, S. Jenny, C. Hollenstein, H. G. Kahle, and A. Geiger (2004), A recent tectonic reorganization in the south-central Mediterranean, Earth Planet. Sci. Lett., 226,335-345, doi:10.1016/j.epsl.2004.07.038.

Gurnis, M., C. Hall, and L. Lavier (2004), Evolving force balance during incipient subduction, Geochem. Geophys. Geosyst., 5, Q07001, doi:10.1029/ 2003GC000681.

Haq, B. U., J. Hardenbol, and P. Vail (1987), Chronology of fluctuating sea-levels since Triassic (250 million years ago to present), Science, 235, 1156-1167, doi:10.1126/science.235.4793.1156.

Heuret, A., F. Funiciello, C. Faccenna, and S. Lallemand (2007), Plate kinematics, slab shape and backarc stress: A comparison between laboratory models and current subduction zones, Earth Planet. Sci. Lett., 256, 473-483, doi:10.1016/j. eps1.2007.02.004.

Hillis, R. R., M. Sandiford, S. D. Reynolds, and M. C Quigley (2008), Present-day stresses, seismicity and Neogene-to-Recent tectonics of Australia's "passive" margins; intraplate deformation controlled by plate boundary forces, Geol. Soc. Spec. Publ. 306, 71-90, doi:10.1144/SP306.3.

Holford, S. P., P. F. Green, J. P. Turner, G. A. Williams, R. R. Hillis, D. R. Tappin, and Y. R. Duddy (2008), Evidence for kilometre-scale Neogene exhumation driven by compressional deformation in the Irish Sea basin system, Geol. Soc. Spec. Publ., 306, 91-119, doi:10.1144/SP306.4.

House, M. A., M. Gurnis, P. J. J. Kamp, and R. Sutherland (2002), Uplift in the Fiordland region, New Zealand: Implications for incipient subduction, Science, 297, 2038-2041, doi:10.1126/science.1075328

Hsü, K. J., L. Montadert, D. Bernoulli, M. B. Cita, A. Erickson, R. E. Garrison, R. B. Kidd, F. Melieres, C. Muller, and R. Wright (1978), History of the Mediterranean salinity crisis, Inital Rep. Deep Sea Drill. Proj., 42(1), 1053-1078.

Jackson, C. A. L., and E. Larsen (2008), Temporal constraints on basin inversion provided by $3 \mathrm{D}$ seismic and well data: A case study from the South Viking Graben, offshore Norway, Basin Res., 20, 397-417, doi:10.1111/j.1365-2117.2008.00359.x.

Jolivet, L., and C. Faccenna (2000), Mediterranean extension and the Africa-Eurasia collision, Tectonics, 19, 1095-1106, doi:10.1029/2000TC900018.

Jolivet, L., C. Faccenna, B. Goffé, E. Burov, and P. Agard (2003), Subduction tectonics and exhumation of high pressure metamorphic rocks in the Mediterranean orogens, Am. J. Sci., 303 , 353-409, doi:10.2475/ajs.303.5.353.

Jongsma, D. J. E. Van Hinte, and J. M. Woodside (1985), Geologic structure and neotectonics of the north African continental margin south of Sicily, Mar. Pet. Geol., 2, 156-179, doi:10.1016/02648172(85)90005-4

Keep, M., and M. Harrowfield (2008), Elastic flexure and distributed deformation along Australia's North West Shelf: Neogene tectonics of the Bonaparte and Browse basins, Geol. Soc. Spec. Publ., 306, 185 200, doi:10.1144/SP306.9.

Kherroubi, A., J. Déverchère, A. K. Yelles, B. Mercier de Lépinay, A. Domzig, A. Cattaneo, R. Bracene,
V. Gaullier, and D. Graindorge (2009), Recent and active deformation pattern off the easternmost Algerian margin, western Mediterranean Sea: New evidence for contractional tectonic reactivation, Mar. Geol., 261(1-4), 17-32, doi:10.1016/j. margeo.2008.05.016.

Krawczyk, C. M. T. J. Reston, M-O. Beslier, and G. Boillot (1996), Evidence for detachment tectonics on the Iberia Abyssal Plain rifted margin, Proc. Ocean Drill. Program Sci. Results, 149, 603-615.

Lemoine, M., G. Dardeau, P.-Y. Delpech, T. Dumont, P. C. De Graciansky, R. Graham, L. Jolivet, D. Roberts, and P. Tricart (1989), Extension syn-rift et failles transformantes jurassiques dans les Alpes Occidentales, C. R. Acad. Sci. Ser. IIa Sci. Terre Planetes, $309,1711-1716$

Lepvrier, C. P. (1967), Structure du massif du Chenoua, Bull. Soc. Geol. Fr., 7, 859-864.

Lofi, J., C. Gorini, S. Berné, G. Clauzon, A. T. Dos Reis, W. B. F. Ryan, and M. S. Steckler (2005), Erosional processes and paleo-environmental changes in the western Gulf of Lions (SW France) during the Messinian salinity crisis, Mar. Geol., 217, 1-30, doi:10.1016/j.margeo.2005.02.014.

Maillard, A., and A. Mauffret (1999), Crustal structure and riftogenesis of the Valencia Trough (northwestern Mediterranean Sea), Basin Res., 11, 357379, doi:10.1046/j.1365-2117.1999.00105.x.

Maillard, A., V. Gaullier, B. Vendeville, and F. Odonne (2003), Influence of differential compaction above basement steps on salt tectonics in the LigurianProvençal Basin, northwest Mediterranean, Mar Pet. Geol., 20, 13-27, doi:10.1016/S0264-8172 (03)00022-9

Mart, Y., E. Aharonov, G. Mulugeta, W. Ryan, T. Tentler, and L. Goren (2005), Analogue modelling of the initiation of subduction, Geophys. J. Int., 160, 10811091, doi:10.1111/j.1365-246X.2005.02544.x.

Mauffret, A. (2007), The Northwestern boundary of the Nubia (Africa) plate, Tectonophysics, 429(1-2), 2144, doi:10.1016/j.tecto.2006.09.007.

Mauffret, A., M. El-Robrini, and M. Gennesseaux (1987), Indices de la compression récente en mer Méditerranée: Un bassin losangique sur la marge nord-algérienne, Bull. Soc. Geol. Fr., 6, 1195-1206.

Mauffret, A., A. Maldonado, and A. C. Campillo (1992), Tectonic framework of the eastern Alboran and western Algerian basins, western Mediterranean, Geo Mar. Lett., 12, 104-110, doi:10.1007/ BF02084919.

Maury, R. C., et al. (2000), Post-collisional Neogene magmatism of the Mediterranean Maghreb margin: A consequence of slab break off, C. R. Acad. Sci. Ser. IIa Sci. Terre Planetes, 331, 159-173.

Meghraoui, M. (1991), Blind reverse faulting system associated with the Mount Chenoua-Tipaza earthquake of 29 October 1989 (north-central Algeria), Terra Nova, 3, 84-93, doi:10.1111/j.13653121.1991.tb00847.x

Meghraoui, M., S. Maouche, B. Chemaa, Z. Cakir, A. Aoudia, A. Harbi, P.-J. Alasset, A. Ayadi, Y. Bouhadad, and F. Benhamouda (2004), Coastal uplift and thrust faulting associated with the $M_{w}=$ 6.8 Zemmouri (Algeria) earthquake of 21 May, 2003, Geophys. Res. Lett., 31, L19605, doi:10.1029/2004GL020466.

Monié, P., R. Caby, and H. Maluski (1984), 40Ar/39Ar investigations within the Grande-Kabylie Massif (northern Algeria): Evidences for its Alpine structuration, Eclogae Geol. Helv., 77, 115-141.

Peron-Pinvidic, G., G. Manatschal, S. M. Deam, and T. A. Minshull (2008), Compressional structures on the West Iberia rifted margin: Controls on their distribution, Geol. Soc. Spec. Publ., 306, 169-183, doi:10.1144/SP306.8.

Pesquer, D. A., I. Grevenmeyer, C. R. Ranero, and J. Gallart (2008), Seismic structure of the passive continental margin of SE Spain and the SW Balearic promontory, western Mediterranean Sea, Eos Trans. $A G U, 89(53)$, Fall Meet. Suppl., Abstract 1340H.
Peucat, J. J., Y. Mahdjoub, and A. Drareni (1996), $\mathrm{U}-\mathrm{Pb}$ and $\mathrm{Rb}-\mathrm{Sr}$ geochronological evidence for late Hercynian tectonic and Alpine overthrusting in Kabylian metamorphic basement massifs (northeastern Algeria), Tectonophysics, 258, 195-213, doi:10.1016/0040-1951(95)00197-2.

Raymond, D. (1976), Evolution sédimentaire et tectonique du nord-ouest de la Grande Kabylie (Algérie) au cours du cycle alpin, Ph.D. thesis, 160 pp., Univ. Pierre et Marie Curie, Paris.

Réhault, J.-P., G. Boillot, and A. Mauffret (1984), The western Mediterranean basin geological evolution, Mar. Geol., 55, 447-477, doi:10.1016/0025-3227 (84)90081-1.

Ritchie, J. D., H. Johnson, M. F. Quinn, and R. W. Gatliff (2008), The effects of Cenozoic compression within the Faroe-Shetland Basin and adjacent areas, Geol. Soc. Spec. Publ, 306, 121-136, doi:10.1144/ SP306.5.

Rivière, M., J.-P. Bouillin, C. Courtois, J.-P. Gélard, and J.-F. Raoult (1977), Etude minéralogique et géochimique des tuffites découvertes dans l'OligoMiocène Kabyle (Grande Kabylie, Algérie). Comparaison avec les Tuffites de la région de Malaga (Espagne), Bull. Soc. Geol. Fr., 19, 1171-1177.

Roca, E., D. Frizon de Lamotte, A. Mauffret, R. Bracene, J. Vergés, N. Benaouali, M. Fernandez, J. A. Muñoz, and H. Zeyen (2004), TRANSMED transect II, in The TRANSMED Atlas-The Mediterranean Region From Crust to Mantle [CD-ROM], edited by W. Cavazza et al., pp. 1-141, Springer, Berlin.

Rogers, C., P. J. van Ruth, and R. R. Hillis (2008), Fault reactivation in the Port Campbell Embayment with respect to carbon dioxide sequestration, Otway Basin, Australia, Geol. Soc. Spec. Pub., 306, 201-214 doi:10.1144/SP306.10.

Rollet, N., J. Déverchère, M.-O. Beslier, P. Guennoc, J.-P. Réhault, M. Sosson, and C. Truffert (2002), Back-arc extension, tectonic inheritance, and volcanism in the Ligurian Sea, western Mediterranean, Tectonics, 21(3), 1015 , doi:10.1029/ $2001 \mathrm{TC} 900027$

Rosenbaum, G., and G. S. Lister (2004), Formation of arcuate orogenic belts in the western Mediterranean region, Geol. Soc. Am. Spec. Publ., 383, 41-56.

Rosenbaum, G., G. S. Lister, and C. Duboz (2002), Reconstruction of the tectonic evolution of the western Mediterranean since the Oligocene, in Reconstruction of the Evolution of the Alpine-Himalayan Orogen, edited by G. Rosenbaum, and G. S. Lister, pp. 107-126, Virtual Explor., Clear Range, N. S. W. Australia.

Rothé, J. P. (1950), Les séismes de Kherrata et la sismicité de l'Algérie, Bull. Serv. Carte Geol. Alger. Ser. $4,3,3-40$.

Rubino, J.-L., G. Clauzon, H. Mezla, and P. Casero (2007), Les canyons messiniens et leur remplissage Pliocène le long de la Marge Nord Africaine, paper presented at lle Congrès Français de Sédimentologie, Caen Univ., Caen, France, 23-25 Oct.

Ryan, W. B. F., and M. B. Cita (1978), The nature and distribution of the Messininan erosional surfaceIndicators of a several-kilometers-deep Mediterranean in the Miocene, Mar. Geol., 27, 193-230, doi:10.1016/0025-3227(78)90032-4.

Saadallah, A., and R. Caby (1996), Alpine extensiona detachment tectonics in the Grande Kabylie metamorphic core complex of the Maghrebides (northern Algeria), Tectonophysics, 267, 257-273, doi:10.1016/S0040-1951(96)00101-1.

Saadallah, A., D. Belhai, H. Djellit, and N. Seddik (1996), Dextral fault motion between the interna and external zones of the Maghrebides, and flowe structure in the Limestone Range, Djurdjura Massif, Algeria, Geodin. Acta, 9, 177-188.

Sage, F., G. Von Gronefeld, J. Déverchère, V. Gaullier, A. Maillard, and C. Gorini (2005), Seismic evi dence for Messinian detrital deposits at the western Sardinia margin, northwestern Mediterranean, Mar. Pet. Geol., 22, 757-773. 
Schettino, A., and E. Turco (2006), Plate kinematics of the western Mediterranean region during the Oligocene and Early Miocene, Geophys. J. Int., 166, 1398-1423, doi:10.1111/j.1365246X.2006.02997.x.

Serpelloni, E., M. Anzidei, P. Baldi, G. Casula, and A. Galvani (2005), Crustal velocity and strain-rate fields in Italy and surrounding regions: New results from the analysis of permanent and non-permanent GPS networks, Geophys. J. Int., 161, 861-880.

Serpelloni, E., G. Vannucci, S. Pondrelli, A. Argnani, G. Casula, M. Anzidei, P. Baldi, and P. Gasperini (2007), Kinematics of the western Africa-Eurasia plate boundary from focal mechanisms and GPS data, Geophys. J. Int., 169(3), 1180-1200, doi:10.1111/j.1365-246X.2007.03367.x.

Stearn, C. E., and D. L. Thurber (1965), 230Th-234U dates of late Pleistocene marine fossils from the Mediterranean and Moroccan littorals, Quaternaria, 7, 29-42.

Stich, D., E. Serpelloni, F. Mancilla, and J. Morales (2006), Kinematics of the IberiaMaghreb plate contact from seismic moment tensors and GPS observations, Tectonophysics, 426(3-4), 295-317, doi:10.1016/j.tecto.2006.08.004.

Tamaki, K., and E. Honza (1985), Incipient subduction and obduction along the eastern margin of the Japan Sea, Tectonophysics, 119, 381-406, doi:10.1016/0040 1951(85)90047-2.

Toth, J., and M. Gumis (1998), Dynamics of subduction initiation at preexisting fault zones, J. Geophys. Res., 103, 18,053-18,067, doi:10.1029/98JB01076.

Vanbrabant, Y., J. Braun, and D. Jongmans (2002), Models of passive margin inversion: Implications for the Rheno-hercynian fold-and-thrust belt, Belgium and Germany, Earth Planet. Sci. Lett., 202, 15-29, doi:10.1016/S0012-821X(02)00751-3.
Yassini, I. (1975), Planktonic foraminiferal biozonation of Neogene deposits in the "Sahel" of Algiers, Alger. Hiv. Ital. Paleont., 81, 11-18.

Yelles, A. K, et al. (2009), Plio-Quaternary reactivation of the Neogene margin off NW Algiers, Algeria: The Khayr-Al-Din bank, Tectonophysics, 475, 98-116, doi:10.1016/j.tecto.2008.11.030.

Yelles-Chaouche, A.-K., J. Roger, J. Déverchère, R. Bracene, A. Domzig, H. Hebert, and A. Kherroubi (2009), The 1856 tsunami of Djidjelli (eastern Algeria): Seismotectonics, modelling, and hazards implications for the Algerian coast, Pure Appl. Geophys., 166, 283-300, doi:10.1007/s00024-008-0433-6.

N. Babonneau and J. Déverchère, Domaines Océaniques, UMR 6538, Université de Brest Occidentale, IUEM, CNRS, Pl. Nicolas Copernic, F-29280 Plouzané, France. (jacdev@univ-brest.fr)

A. Boudiaf and K. Yelles, CRAAG, Rte. de l'Observatoire, BP 63, Bouzareah, 16340 Algiers, Algeria.

A. Cattaneo, Laboratoire Environnements Sédimentaires, Département Géosciences Marines, IFREMER, F-29280 Plouzané, France.

A. Domzig, Midland Valley Exploration Ltd., 144 West George St., Glasgow G2 2HG, UK.

B. Mercier de Lépinay, GéoAzur, UMR 6526, Université de Nice Sophia Antipolis, CNRS, 250 Rue A. Eisntein, F-06560 Valbonne, France.

P. Strzerzynski, Laboratoire de Planétologie et Géodynamique, UMR 6112 , Université du Maine, CNRS, Ave. Olivier Messiaen, F-72085 Le Mans, France. 